\title{
ANALISA LAW AND ECONOMICS ATAS KOMPENSASI DAN ASURANSI LINGKUNGAN DI INDONESIA: SEBUAH KRITIK ATAS KOMPENSASI TANPA SISTEM
}

\author{
Andri G. Wibisana dan Pramita K. Putri'
}

\begin{abstract}
Compensation mechanisms and liability are an important part in environmental management. Compensation, through liability or other mechanisms, provides not only protection for the victims of environmental damage, but also incentives for the potential polluters to take an ex ante optimal level of care. Ideally, compensation should be first provided through liability (combined with liability insurance). If this system does not work properly, alternatives to liability insurance, i.e. risk-sharing agreement, firstparty insurance, and environmental damage insurance, should be developed. Finally, the system of compensation funds should also be promoted whenever liability system, liability insurance, and alternatives to liability insurance are likely to fail to provide enough protection for the victims and incentives to take care for the potential polluters. Unfortunately, compensation in Indonesian is ill-structured, leaving the victims with tort law as the only way to get compensated. The Sidoarjo mudflow case clearly illustrates the impacts of such an ill-structured compensation system. Theoretically, this situation will be improved, as the new environmental act has acknowledged several alternatives for compensation mechanism.
\end{abstract}

Kata kunci: environmental damage, liability, insurance, compensation funds

\section{Pengantar}

Kompensasi merupakan bagian tidak terpisahkan dari pengelolaan lingkungan. Di satu sisi, sistem kompensasi dimaksudkan untuk memberikan kepastian bahwa korban akan memperoleh ganti kerugian penuh (full compensation), sedang di sisi lain sistem kompensasi tersebut harus mampu

${ }^{1}$ A.G.Wibisana adalah pengajar Hukum Lingkungan dan Hukum Administrasi Negara pada Fakultas Hukum UI, dan Pramita K. Putri memperoleh gelar SH dari FHUI (2009) dengan skripsi mengenai asuransi lingkungan di Indonesia. Korespondensi dialamatkan pada A.G. Wibisana (mragw@yahoo.com). 
mendorong terjadinya internalisasi biaya lingkungan. ${ }^{2}$ Dalam perspektif ekonomi ganti kerugian dianggap telah mencapai perfect compensation ketika pembayaran sejumlah uang yang diberikan kepada korban dapat membuat utilitas korban setelah mengalami kerugian dan menerima uang kompensasi sama dengan kondisi utilitas korban apabila tidak mengalami kerugian dan tidak menerima uang kompensasi. ${ }^{3}$

Selanjutnya, dalam perspektif ekonomi, sistem kompensasi dapat pula berperan dalam mendorong dilakukannya internalisasi biaya lingkungan dalam bentuk upaya pencegahan ex ante. Untuk mencapai tujuan ini, Faure dan Hartlief menyatakan bahwa di satu sisi pembayaran kompensasi haruslah dilakukan hanya oleh mereka yang berkontribusi atas timbulnya kerugian. Di sisi lain, tingkat pembayaran yang dilakukan oleh si pencemar harus memiliki korelasi dengan tingkat kontribusi pencemar terhadap timbulnya kerugian. ${ }^{4}$

Dengan demikian, maka sistem kompensasi berhubungan tidak hanya dengan pemenuhan hak korban pencemaran, tetapi juga dengan efek jera dan upaya pencegahan. Mengingat pentingnya sistem kompensasi ini, maka Deklarasi Rio tahun 1992 telah mengamanatkan pada setiap negara untuk membuat perangkat hukum mengenai pertanggungjawaban perdata dan kompensasi bagi para korban pencemaran.

Tulisan ini bermaksud menjawab pertanyaan mengenai sistem pertanggungjawaban perdata dan kompensasi manakah yang secara teoritis mampu memberikan jawaban atas kebutuhan pemenuhan hak korban sekaligus memberikan insentif internalisasi biaya lingkungan bagi para calon pencemar. Berdasarkan analisa atas pertanyaan tersebut, tulisan ini selanjutnya akan memeriksa perkembangan dan praktek sistem kompensasi yang ada di Indonesia.

Untuk menjawab pertanyaan-pertanyaan tersebut, tulisan ini pertamatama akan membahas mengenai sistem kompensasi berlapis (Bagian I). Selanjutnya berdasarkan teori yang dikemukakan pada Bagian I, Bagian II akan membahas sistem kompensasi yang ada di Indonesia berdasarkan UU

${ }^{2}$ H. Bocken, 1988, "Alternatives to Liability and Liability Insurance for the Compensation of Pollution Damages 2", Tijdscrift voor Milieu Aansprakelijkheid, Vol. 1, hal. 10.

${ }^{3}$ R. Cooter dan T. Ulen, 2000, Law and Economics, $3^{\text {rd }}$ ed. (New York: Addison Wesley Longman), hal. 293.

${ }^{4}$ M. Faure dan T. Hartlief, 1996, "Compensation Fund versus Liability and Insurance for Remedying Environmental Damage", Review of European Community and International Environmental Law, Vol. 5, Issue 4, hal. 322-323. 
No. 23/1997 (UUPLH). Bagian III akan membahas mengenai asuransi lingkungan di Indonesia berdasarkan penelitian lapangan pada 2 (dua) perusahaan asuransi yang menyediakan asuransi lingkungan. Bagian IV merupakan kesimpulan atas analisa terhadap sistem kompensasi di Indonesia. Bagian ini juga akan memaparkan dampak yang muncul akibat dari sistem kompensasi ini. Bagian V (epilog) akan menjelaskan reformasi sistem kompensasi berdasarkan undang-undang lingkungan hidup yang baru, yaitu UU Perlindungan dan Pengelolaan Lingkungan Hidup (UUPPLH). ${ }^{5}$

\section{Sistem Kompensasi Berlapis: Sebuah Pendahuluan}

Pada tahun 1993, European Commission mengeluarkan Green Paper on Remedying Environmental Damage yang berisi arahan tentang sistem kompensasi bagi pencemaran lingkungan. Arahan ini menjelaskan tidak hanya perkembangan pertanggungjawaban perdata bagi pencemaran lingkungan di beberapa negara di Eropa, tapi juga menggambarkan hal-hal yang dapat menyebabkan sistem pertanggung jawaban perdata menjadi tidak berfungsi. Menurut Green Paper, sistem pertanggungjawaban perdata hanya bisa efektif apabila kondisi-kondisi berikut ini terpenuhi: kerugian bisa dihitung dan muncul secara langsung (tidak bersifat laten); kerugian muncul karena tindakan atau insiden tertentu (bukan merupakan akibat dari akumulasi kegiatan/insiden); kerugian disebabkan oleh (kegiatan) pihak yang dapat diidentifikasi; pihak tersebut dapat dimintakan pertanggung jawabannya berdasarkan perbuatan melawan hukum atau strict liability; adanya hubungan kausalitas; dan adanya pihak yang berkepentingan untuk membawa kerugian ke pengadilan. ${ }^{6}$ Green Paper menyatakan bahwa apabila

${ }^{5}$ UUPPLH disahkan oleh DPR pada tanggal 8 September 2009 sebagai ganti dari UU No. 23 tahun 1997 tentang pengelolaan lingkungan hidup (UUPLH).

${ }^{6}$ Commission of European Communities, "Communication from the Commission to the Council and Parliament and the Economic and Social Committee: Green Paper on Remedying Environmental Damage”, COM (93) 47 Final, May 14, 1993, hal. 24.

Bandingkan dengan Shavell, yang menyatakan bahwa pertanggungjawaban perdata lebih efektif dari pada regulasi apabila: pertama, individu memiliki informasi yang lebih baik dari pada pemerintah tentang upaya pengawasan terhadap resiko; kedua, tidak terdapat kemungkinan judgment proof; ketiga, adanya kemungkingan gugatan perdata; keempat, biaya administratif yang lebih murah dari pada regulasi.

Shavell juga menyatakan bahwa kemungkinan munculnya gugatan perdata akan hilang, dan dengan demikian akan mengurangi insentif para pihak untuk mengambil tindakan pencegahan ex ante, karena beberapa sebab, yaitu: pertama, bahaya/kerugian yang muncul mungkin sangat menyebar sehingga bahaya/kerugian tersebut menjadi kecil bagi tiap individu, 
pertanggungjawaban perdata gagal memberikan hasil yang efektif dan memuaskan, maka dana kompensasi dapat dikembangkan sebagai mekanisme pemberian ganti kerugian. ${ }^{7}$ Dengan demikian, sistem kompensasi yang disarankan oleh Green Paper terdiri dari dua lapis, yaitu pertanggungjawaban perdata (disertai dengan asuransi tanggung jawabliability insurance) dan dana kompensasi.

Dalam perkembangannya, ternyata muncul sebuah lapisan baru di antara pertanggungjawaban perdata dan dana kompensasi. Lapisan baru ini terutama muncul sebagai alternatif untuk menjawab berbagai kendala yang dihadapi oleh asuransi tanggung jawab. Karena itu, di dalam tulisan ini, kami mengelompokkan berbagai mekanisme kompensasi ke dalam tiga lapisan, yang kami namakan sistem kompensasi berlapis, ${ }^{8}$ yaitu:

1. Pertanggungjawaban perdata dan asuransi tanggung jawab;

2. Alternatif atas Asuransi Tanggung Jawab; dan

3. Dana Kompensasi.

Masing-masing lapisan dari sistem kompensasi berlapis ini akan dijabarkan pada sub bagian berikut ini.

meskipun secara total bahaya/kerugian sangat besar. Akibat keadaan ini, tidak ada individu yang tertarik untuk membawa kerugiannya ke pengadilan. Kedua, bahaya/kerugian mungkin muncul setelah kurun waktu yang lama, sehingga para korban mengalami kesulitan untuk menunjukkan bukti-bukti yang diperlukan. Ketiga, dalam kasus tertentu, para korban dapat pula mengalami kesulitan untuk menunjukkan bahwa kerugian yang dideritanya disebabkan oleh tergugat (hubungan kausalitas antara kerugian dengan pihak yang bertanggungjawab). Keempat, dalam hal kerugian disebabkan oleh kegiatan usaha dari sebuah perusahaan, gugatan perdata belum tentu memberikan efek jera bagi para pengambil keputusan di perusahaan tersebut, karena memang sangat sulit untuk menentukan siapa di antara para pengambil keputusan tersebut yang benar-benar merupakan orang yang harus bertanggung jawab.

Lihat: S. Shavell, 1984, "Liability for Harm versus Regulation of Safety", Journal of Legal Studies, Vol. 13, hal. 359-363.

${ }^{7}$ Commission of European Communities, 1993, Op. Cit., hal. 28. Istilah yang digunakan oleh EC Green Paper untuk merujuk pada dana kompensasi adalah "joint compensation mechanisms". Penggunaan istilah ini dapat dimengerti mengingat Green Paper memang tidak ditujukan untuk menerangkan mekanisme apa saja yang dapat digunakan sebagai dana kompensasi ini. Untuk lebih jelasnya mengenai dana kompensasi ini, lihat sub bagian IC dari tulisan ini.

${ }^{8}$ A.G. Wibisana, "The Myths of Environmental Compensation in Indonesia: Lessons from Sidoarjo Mudflow", Progress Report for the 2008-2010 KNAW-SPIN Post-doctoral research. 


\section{A. Lapis Pertama Kompensasi: Pertanggungjawaban Perdata dan Asuransi Tanggung Jawab}

Menurut Green Paper, lapis pertama dari sistem kompensasi yang harus bekerja ketika terjadi pencemaran adalah pertanggungjawaban perdata, baik berdasarkan perbuatan melawan hukum (pertanggung jawaban atas dasar kesalahan-liability based on fault atau negligence) maupun berdasarkan pertanggungjawaban langsung (pertanggungjawaban tanpa kesalahan-liability without fault atau strict liability). Terkait dengan pertanggungjawaban atas dasar kesalahan, Green Paper menyatakan bahwa pertanggungjawaban ini memerlukan bukti bahwa pencemar (tergugat) telah melakukan kelalaian atau pelanggaran hukum yang menimbulkan kerugian. Bukti tentang ada tidaknya unsur kesalahan tergantung pada apakah pihak pencemar tersebut memiliki kewajiban menurut standar tertentu (duty of care) dan apakah pencemar tersebut melanggar kewajiban tersebut. Green Paper juga menyatakan bahwa dalam kasus lingkungan, duty of care dapat dilihat pada kewajiban yang muncul dari berbagai peraturan, sehingga pelanggaran terhadap peraturan tersebut dapat menjadi petunjuk tentang adanya kesalahan pada diri pencemar. ${ }^{9}$ Dari uraian Green Paper tersebut dapat disimpulkan bahwa kesalahan di dalam liability based on fault ditunjukkan dengan adanya pelanggaran hukum.

Di dalam praktek, para korban sering kali kesulitan untuk membuktikan unsur kesalahan tersebut, sehingga mereka gagal memperoleh kompensasi atas kerugian yang dideritanya. Dengan demikian, dari konteks perlindungan korban, pertanggungjawaban langsung (strict liability) berguna untuk memperbesar perlindungan bagi para korban, karena pencemar akan bertanggungjawab atas pencemaran yang terjadi, tanpa melihat ada tidaknya unsur kesalahan pada diri pencemar, yaitu apakah pencemar telah melakukan perbuatan melanggar hukum (unlawful act) atau tidak. Pencemar tetap bertanggung jawab meskipun tidak ada kesalahan berupa pelanggaran hukum (pelanggaran terhadap duty of care).

Seperti telah dikemukakan di muka, pertanggungjawaban perdata tidak akan efektif apabila terdapat kemungkinan insolvensi. Untuk menghindari kemungkinan ini, maka di banyak negara penerapan pertanggungjawaban perdata disertai dengan adanya kewajiban pelaku usaha untuk memiliki asuransi tanggung jawab (liability insurance).

${ }^{9}$ Ibid., hal. 6. 
Manfaat utama dari asuransi tanggung jawab lingkungan ini adalah untuk mengalihkan resiko atas kemungkingan terjadinya judgment proof (insolvency), yaitu kondisi di mana aset pencemar tidak mencukupi untuk membayar biaya ganti kerugian yang dibutuhkan untuk merestorasi lingkungan dan juga ganti rugi kepada pihak ketiga (kompensasi). ${ }^{10}$ Dalam Perspektif ekonomi yang dimaksud dengan insolvency adalah keadaan dimana ekspektasi nilai kerugian lebih besar dari pada aset yang dimiliki oleh pelaku usaha.

Terkait dengan persoalan lingkungan, kemungkinan adanya insolvensi dapat berakibat kepada tiga hal, yaitu: ${ }^{11}$

1. Berkurangnya tingkat pencegahan yang dilakukan oleh pelaku usaha (under-deterrence)

Hal ini terjadi karena secara teoritis dapat dilihat bahwa tingkat kehati-hatian dari calon pencemar akan terkait dengan besarnya ganti kerugian yang harus dibayar olehnya. Semakin tinggi kemungkinan ganti kerugian, maka calon pencemar tersebut akan semakin berhati-hati dalam menjalankan usaha/kegiatannya. Apabila calon pencemar mengetahui bahwa asetnya tidak akan mencukupi untuk membayar kerugian yang diderita korban, maka dengan sendirinya insentif untuk bertindak hati-hati pun akan berkurang. ${ }^{12}$

${ }^{10}$ Istilah Judgment Proof seringkali digunakan untuk menyatakan keadaan dimana pihak pencemar tidak memiliki aset, dan karena itu ia tidak dapat membayar ganti rugi yang dibebankan oleh hakim kepadanya. Tapi pada makalah ini istilah Judgment Proof digunakan untuk menyatakan keadaan dimana pencemar tidak dapat membayar secara penuh ganti rugi yang dibebankan oleh hakim kepadanya. S. Shavell, 1986, "The Judgment Proof Problem" in International Review of Law and Economics, Vol. 6, hal. 45.

11 M. Faure dan D. Grimeaud, 2003, "Part I: Financial Assurance Issues of Environmental Liability", dalam: M. Faure (ed.), Deterrence, Insurability, and Compensation in Environmental Liability: Future Developments in the European Union (Wina: Springer), hal. 183-185.

${ }^{12}$ Kondisi ini terutama sekali terjadi pada strict liability, karena apabila aset pencemar kurang dari kerugian actual, maka pencemar akan mengambil tindakan kehati-hatian yang kurang dari tingkat yang optimal. Sedangkan pada sistem tanggung jawab atas dasar kesalahan, pencemar mungkin akan tetap mengambil tingkat kehati-hatian yang optimal sepanjang asetnya lebih besar dari pada biaya yang dibutuhkan untuk mengambil tingkat yang optimal tersebut. Lihat: A.M. Polinsky and S. Shavell, 1992, "Optimal Cleanup and Liability after Environmentally Harmful Discharges", NBER Working Paper No. 4176, 1992, hal. 7-8.

Di samping akan mengurangi insentif untuk bertindak hati-hati, judgment proof juga dapat berpengaruh pada tingkat aktivitas (activity level) dari kegiatan yang berpotensi 
2. Berkurangnya nilai ganti rugi yang didapatkan oleh korban (under-compensation)

Dari perspektif ekonomi, kompensasi secara penuh dicapai ketika dengan adanya kompensasi maka tingkat utilitas korban sebelum dan setelah mengalami kerugian menjadi sama. Jika insolvensi terjadi, korban akan menerima kompensasi yang kurang dari kerugian yang dialaminya. Ini berarti tingkat utilitas korban setelah menderita kerugian (dan kemudian menerima kompensasi) tetap lebih rendah dari pada tingkat utilitas sebelum ia mengalami kerugian tersebut.

3. Terjadinya eksternalisasi (externalization through insolvency)

Externalization through insolvency adalah munculnya eksternalitas negatif akibat kurangnya aset yang dimiliki pencemar. Contoh: dikarenakan kurangnya asset, pencemar gagal untuk membayar seluruh biaya yang dibutuhkan untuk memperbaiki kondisi lingkungan yang rusak akibat pencemaran, sehingga masyarakatlah yang pada akhirnya dibebankan biaya-biaya tersebut. ${ }^{13}$

Dengan adanya asuransi tanggung jawab, maka permasalahan underdeterrence, undercompensation, dan externalization through insolvcency dapat diatasi. Selain itu asuransi ini akan menyediakan pula perlindungan terhadap tertanggung atas kemungkinan terjadinya resiko-resiko di luar kekuasaan, di mana apabila resiko-resiko tersebut terjadi, maka tidak akan mengakibatkan tertanggung menjadi

menimbulkan bahaya. Artinya, jika pencemar tahu bahwa asetnya kurang dari kerugian yang aktual, maka insentif untuk mengurangi jumlah kegiatan yang berbahaya akan berkurang pula. Secara umum ini berarti bahwa orang yang terlibat dalam kegiatan yang beresiko tinggi menjadi terlalu banyak. S. Shavell (2003), "Economic Analysis of Accident Law", NBER Working Paper No. 9694, 2003, Bab 4, hal. 5.

${ }^{13}$ Dari perspektif ekonomi, pencemaran adalah sebuah bentuk eksternalitas, yaitu kondisi yang terjadi ketika biaya-biaya lingkungan tidak dimasukkan dalam pengambilan keputusan individu. Hal ini ditunjukkan dengan adanya perbedaan antara biaya sosial (social cost) dan biaya individual (private cost). Oleh para ekonom, kondisi semacam ini dianggap tidak efisien, karena harga produk yang dihasilkan dari sebuah eksternalitas tidak akan mencerminkan harga atau biaya yang sesungguhnya (true social cost). Lihat misalnya: R.S. Pindyck and D.L. Rubenfield, 2001, Microeconomics (New Jersey: Prentice Hall, 2001), hal. 592; dan E.J. Solberg, 1982, Intermediate Microeconomics (Texas: Business Publication), hal. 540 . 
bangkrut. Di samping itu, asuransi ini juga sedikit banyak dapat memberikan jaminan bahwa biaya yang dibutuhkan untuk merestorasi lingkungan yang rusak atau tercemar dapat tersedia secara cepat.

Perlu pula diutarakan di sini bahwa pencegahan insolvensi tidak hanya dapat dilakukan melalui asuransi tanggung jawab, tetapi juga melalui jaminan keuangan lainnya. Dalam hal ini, seperti tercantum dalam RUU lingkungan Flemish, jaminan keuangan bisa berupa: asuransi tanggung jawab, garansi yang disediakan oleh lembaga keuangan, bentuk jaminan keuangan personal, dan deposito yang disimpan dalam akun khusus sebagai dana jaminan. ${ }^{14}$ Dengan demikian, jaminan keuangan untuk menghindari insolvensi dapat terdiri dari beberapa pilihan. Pemerintah lah yang kemudian berperan untuk menentukan apakah instrumen jaminan keuangan yang dipilih telah cukup layak dan memadai untuk menghindari insolvensi.

\section{B. Lapis Kedua Kompensasi: Alternatif atas Asuransi Tanggung Jawab}

Meskipun pemberlakuan asuransi tanggung jawab hukum memiliki peran yang penting sebagai salah satu mekanisme kompensasi, akan tetapi ternyata asuransi ini memiliki beberapa persoalan besar. ${ }^{15}$ Dengan adanya persoalan ini, maka muncullah

14 M. Faure, 2004, "Alternative Compensation Mechanisms as Remedies for Uninsurability of Liability", The Geneva Papers on Risk and Insurance, Vol. 29, No. 3, hal. 475-476. Faure juga menjelaskan bahwa berbeda dengan jaminan keuangan lainnya, deposito bersifat refundable dalam artian bahwa dana ini akan dikembalikan apabila pencemar telah memenuhi kewajibannya. Lihat: Ibid., hal. 478. Di AS, deposito ini disebut sebagai performance bond. Menurut Boyd, perbedaan utama antara jaminan berdasarkan asuransi dengan jaminan berdasarkan bond terletak pada resiko yang ingin dijamin. Dalam bond, jaminan ditujukan pada kewajiban-kewajiban yang sebelumnya telah diketahui dan harus terjadi, sedangkan dalam jaminan berdasarkan asuransi, jaminan ditujukan untuk hal-hal yang hanya dapat diprediksi tetapi masih bersifat resiko (belum pasti). Lihat: J. Boyd, 2003, "A Market-Based Analysis of Financial Insurance Issues Associated with US Natural Resource Damage Liability", dalam: M. Faure (ed.), 2003, Deterrence, Insurability, and Compensation in Environmental Liability: Future Developments in the European Union (Wina: Springer), hal. 262-263.

${ }^{15}$ Faure mencatat sedikitnya terdapat enam persoalan yang muncul dalam asuransi tanggung jawab. Pertama, pihak asuransi seringkali tidak memiliki informasi yang memadai mengenai resiko yang mungkin muncul. Ketidakpastian informasi ini dapat berupa ketidakpastian dalam hal hukum, misalnya ketidakpastian penegakan hukum, ataupun ketidakpastian mengenai kerugian aktual, di mana informasi mengenai probabilitas munculnya kerugian dan tingkat keseriusan kerugian belum tersedia. Kedua, adanya ketidakpastian mengenai ruang lingkup pertanggungjawaban, terutama terkait dengan pertanggungjawaban 
beberapa mekanisme kompensasi sebagai alternatif atas asuransi tanggung jawab. Beberapa alternatif ini adalah:

\section{Perjanjian Pembagian Resiko (Risk Sharing Agreement)} Perjanjian pembagian resiko merupakan alternatif mekanisme kompensasi yang sangat atraktif terutama ketika informasi tentang probabilitas dan besarnya kerugian masih sangat kurang. Berbeda dengan asuransi, di mana premi ditentukan berdasarkan informasi mengenai kerugian, perjanjian pembagian resiko dapat tetap berjalan meskipun informasi tersebut masih sangat sedikit, sebab yang dibutuhkan dalam perjanjian ini adalah kontribusi relatif dari pihak-pihak yang terlibat dalam perjanjian. Di samping itu, perjanjian ini pun dapat berfungsi sebagai upaya untuk mengontrol moral hazard, karena setiap pihak yang terlibat dalam perjanjian ini memiliki kepentingan untuk mengontrol

atas kerusakan/pencemaran lingkungan (environmental damage). Mengingat asuransi akan bekerja efektif apabila kerugian dapat diidentifikasi dan diukur, maka ruang lingkup pertanggungjawaban yang luas dapat mengganggu kerja sistem asuransi. Ketiga, asuransi sering pula berhadapan dengan ketidakpastian mengenai ruang lingkup kerugian. Hal ini terjadi karena kerugian akibat dari pencemaran/kerusakan lingkungan sering kali sangat besar, melebihi kapasitas asuransi untuk menanggung kerugian tersebut. Keempat, asuransi juga seringkali mengalami kesulitan dalam mengontrol tingkah laku tertanggung, yang pada gilirannya akan menimbulkan apa yang disebut sebagai moral hazard dan adverse selection. Moral hazard muncul ketika pihak tertanggung akan mengurangi tingkat kehati-hatiannya justru setelah adanya asuransi bagi kegiatannya. Hal ini berakibat pada semakin besarnya kemungkinan terjadinya kerugian, yang tidak hanya merugikan pihak asuransi, tapi juga merugikan masyarakat sebab resiko munculnya kerugian justru akan semakin besar setelah adanya asuransi. Adverse selection terjadi apabila asuransi gagal mengaitkan antara resiko kegiatan tertanggung dengan premi yang harus dibayarnya. Idealnya, premi yang dibayarkan oleh tertanggung harus mencerminkan tingkat resiko dari tertanggung. Apabila hal ini tidak terjadi, maka mereka yang beresiko tinggi memiliki premi yang relatif sama dengan yang beresiko rendah. Akibatnya, asuransi justru hanya menguntungkan mereka yang beresiko tinggi, tetapi merugikan mereka yang beresiko rendah. Pada akhirnya, adverse selection ini dapat berakibat pada hancurnya industri asuransi, sebab asuransi hanya akan diisi oleh mereka yang beresiko tinggi saja. Kelima, asuransi pertanggungjawaban sering kali pula menghadapi persoalan terkait dengan ketidakpastian mengenai kausalitas. Apabila hakim memberlakukan pembuktian terbalik terkait kausalitas, maka hal ini akan beresiko pada semakin besarnya kemungkin tergugat akan dianggap sebagai pihak yang bertanggung jawab, dan pada gilirannya akan meningkatkan pula kemungkinan pembayaran kompensasi oleh pihak asuransi. Keenam, persoalan asuransi tanggung jawab juga terkait dengan pertanggung jawaban untuk "long-tail risks", yaitu resiko yang muncul setelah periode waktu yang cukup lama. Persoalannya dengan resiko secamam ini adalah adanya kemungkinan bahwa pihak asuransi harus membayar kerugian untuk sebuah perbuatan yang dilakukan sebelum tertanggung memiliki asuransi. Lihat: M. Faure, 2007a, "A Shift toward Alternative Compensation Mechanisms for Environmental Damage?", dalam: M. Faure dan A. Verheij (eds.), Shifts in Compensation for Environmental Damage (Vienna: Springer), hal. 75-78. 
kinerja pihak lain guna mengurangi kemungkinan terjadinya kerugian. Contoh dari perjanjian pembagian resiko adalah perjanjian para operator nuklir berdasarkan Price-Anderson Act di AS dan perjanjian antara para pemilik kapal tanker untuk terlibat di dalam perjanjian pembagian resiko atas kerugian akibat pencemaran minyak di laut (Protection and Indemnity Clubs$P \& I C l u b s) .{ }^{16}$

\section{Asuransi Pihak Pertama (first party insurance)}

Di beberapa negara, seperti Perancis, asuransi pihak pertama dapat pula berfungsi sebagai alternatif mekanisme kompensasi bagi para korban pencemaran. Dalam model asuransi pihak pertama di Perancis, asuransi akan membayarkan kompensasi kepada korban, baik kompensasi atas kerugian materil maupun immaterial (non-pecuniary losses), tanpa melihat apakah ada pihak yang harus bertanggung jawab atas kerugian yang diderita oleh korban (tertanggung). ${ }^{17}$

Dalam First Party Insurance, penanggung menjamin pencemaran/kerusakan yang terjadi di dalam obyek pertanggungan yang merupakan akibat langsung dari kegiatan tertanggung. Dengan kata lain, tertanggung dalam asuransi ini adalah para korban. Karena dalam asuransi ini tertanggung yang akan menerima kompensasi atas kerugian yang dideritanya, asuransi ini juga disebut dengan asuransi kerugian.

Meski demikian, perlu pula ditegaskan di sini bahwa asuransi ini memiliki kelemahan mendasar, yaitu bahwa dalam asuransi ini premi dibayar oleh korban, dan bukan oleh pencemar. Hal ini tentu saja bertentangan dengan prinsip pencemar membayar. Mengingat persoalan ini, maka Faure menolak jika asuransi pihak pertama untuk kerugian lingkungan dijadikan sebagai sebuah asuransi wajib. ${ }^{18}$

${ }^{16}$ Ibid., hal. 78-79.

${ }^{17}$ M. Faure, 2006, "Economic Criteria for Compulsory Insurance", The Geneva Papers on Risk and Insurance: Issues and Practice, Vol. 31, hal. 165.

${ }^{18} \mathrm{Di}$ samping persoalan distribusi resiko di atas, Faure menambahkan bahwa asuransi kerugian pun tidak bisa dijadikan asuransi wajib karena asuransi ini akan pula menanggung kerugian immaterial. Persoalannya dari kerugian immaterial ini adalah bahwa kerugian ini sulit untuk dikonversi ke dalam uang, sehingga di satu sisi akan sulit pula menemukan calon 


\section{Asuransi Kerugian Lingkungan (Environmental Damage Insurance)}

Faure mencatat satu jenis asuransi lingkungan di Belanda yang layak untuk kita jadikan lapisan kedua di dalam sistem kompensasi. Sejak tahun 1998 di Belanda berlaku asuransi kerugian lingkungan (millieuschadeverzekering), sebagai ganti dari asuransi tanggung jawab (liability insurance). Dalam asuransi kerugian lingkungan ini, penanggung jawab kegiatan/ usaha mengasuransikan tempat atau resiko dari kegiatan/ usahanya. Berbeda dengan asuransi pertanggung jawaban, dalam sistem asuransi kerugian lingkungan pembayaran kompensasi dari pihak asuransi dipicu oleh munculnya kerugian, dan bukan oleh adanya pertanggungjawaban perdata dari pihak tertanggung (dalam hal ini penanggung jawab usaha/kegiatan). Di samping itu, kompensasi diberikan tidak hanya kepada pihak tertanggung, tetapi juga kepada pihak ketiga yang mengalami kerugian dari kegiatan/usaha pihak tertanggung. Asuransi kerugian lingkungan dengan demikian merupakan pergeseran dari sistem asuransi pihak ketiga (third party insurace) ke arah asuransi pihak pertama (first party insurance). ${ }^{19}$

Namun demikian, perlu pula kiranya diutarakan bahwa asuransi kergugian lingkungan tetap berbeda dengan asuransi pihak pertama: apabila dalam asuransi pihak pertama premi asuransi dibayarkan oleh calon korban, dalam asuransi kerugian lingkungan premi dibayar oleh para calon pencemar. ${ }^{20}$ Perbedaan ini penting untuk diperhatikan karena asuransi lingkungan yang preminya dibayar oleh korban dapat dikatakan bertentangan dengan rasa keadilan di samping juga tentunya melanggar asas pencemar membayar. ${ }^{21}$

Pengalaman asuransi kerugian lingkungan (environmental damage insurance) di Belanda muncul terutama karena inisiatif

korban yang ex ante mau mengasuransikan kerugian immaterialnya, sedang di sisi lain pihak asuransi pun akan kesulitan melakukan diferensiasi resiko dan menentukan harga premi mengingat kerugian semacam ini bersifat subyektif. Ibid., hal. 165-166.

${ }^{19}$ M. Faure, 2004, Op. Cit., hal. 466-471.

${ }^{20}$ Ibid., hal. 468.

${ }^{21}$ H. Bocken, 1987, "Alternatives to Liability and Liability Insurance for the Compensation of Pollution Damages 1", Tijdscrift voor Milieu Aansprakelijkheid Vol. 4, hal 83. 
dari pihak asuransi. Mereka menginginkan adanya jenis asuransi yang lebih pasti dan lebih memudahkan mereka untuk mengontrol tingkah laku dari pihak tertanggung. ${ }^{22}$ Mengingat dalam asuransi tanggung jawab, pembayaran kompensasi sangat tergantung pada penegakan hukum perdata dan interpretasi hakim atas kasus pencemaran yang terjadi, maka kontrol pihak asuransi terhadap tertanggung menjadi berkurang.

Di samping itu, asuransi kerugian lingkungan juga memberikan manfaat yang sangat besar terhadap para korban pencemaran, karena melalui asuransi ini, pembayaran kompensasi terhadap para korban dapat dilakukan tanpa harus menunggu proses pengadilan untuk menentukan apakah tertanggung bertanggung jawab atas kerugian korban atau tidak. Tentu saja, pembayaran kompensasi ini disertai dengan penyerahan hak gugatan dari korban kepada pihak asuransi (subrogasi).

Dari uraian di atas dapat disimpulkan bahwa asuransi lingkungan dapat mengambil tiga bentuk, yaitu Asuransi Pihak Ketiga, yang termasuk pada lapis pertama kompensasi, serta Asuransi Pihak Pertama dan Asuransi Kerugian Lingkungan yang termasuk pada lapis kedua sistem kompensasi. ${ }^{23}$ Berbeda dari

${ }^{22}$ M. Faure, 2004, Op. Cit., hal. 470

${ }^{23}$ Untuk memudahkan, ada baiknya ketiga jenis asuransi tersebut kami uraikan sebagai berikut:

1. Asuransi pihak pertama (First Party Insurance)

Dalam First Party Insurance, penanggung menjamin pencemaran/kerusakan yang terjadi di dalam obyek pertanggungan yang merupakan akibat langsung dari kegiatan tertanggung. Karena dalam asuransi ini, tertanggung yang akan menerima kompensasi atas kerugian yang dideritanya, di Indonesia asuransi ini juga disebut dengan asuransi kerugian.

2. Asuransi pihak ketiga (Third Party Insurance)

Dalam Third Party Insurance, penanggung menjamin kemungkinan tertanggung dinyatkan bertanggung jawab untuk membayar kompensasi atau setiap pencemaran/kerusakan yang merugikan pihak ketiga. Karena asuransi ini mensyaratkat adanya tanggung jawab perdata pada diri tertanggung, maka asuransi seperti ini disebut juga dengan asuransi tanggung jawab (liability insurance).

3. Asuransi kerusakan lingkungan (Direct insurance for Environmental Damage)

Dalam Direct Insurance for Environmental Damage, penanggung menjamin pencemaran/kerusakan yang terjadi baik di dalam obyek pertanggungan maupun di luar obyek pertanggungan yang merupakan akibat langsung dari kegiatan tertanggung, dan juga atas kemungkianan tertanggung dinyatakan bertanggung jawab untuk membayar kompensasi atas setiap pencemaran/kerusakan yang merugikan pihak ketiga. 
tujuan asuransi sebagai jaminan keuangan untuk mencegah terjadinya judgment proof (seperti pada asuransi tanggung jawab), asuransi kerugian terutama bertujuan sebagai upaya untuk menghindarkan kerugian besar pada diri tertanggung yang tidak suka akan resiko (risk averse). ${ }^{24}$

Perbedaan penting lainnya dari asuransi tanggung jawab dan asuransi kerugian adalah pada asuransi tanggung jawab pihak yang paling berkepentingan akan adanya asuransi adalah calon korban (pihak ketiga), sedangkan pada asuransi kerugian, pihak yang paling berkepentingan akan adanya asuransi adalah tertanggung itu sendiri.

\section{Lapis Ketiga Kompensasi: Dana Kompensasi}

Apabila pertanggungjawaban perdata tidak bisa berjalan, misalnya karena pencemar tidak diketahui, Green Paper mengusulkan diberlakukannya kompensasi bersama atau dana kompensasi (compensation funds) sebagai lapis terakhir dari sistem kompensasi.

Salah satu contoh yang layak dirujuk untuk dana kompensasi ini adalah lembaga Superfund yang berlaku di AS. Dana Superfund dipungut dari industri yang berpotensi melakukan pembuangan limbah beracun (B3), seperti industri kimia dan migas. Dana ini kemudian dikelola oleh negara, dan selanjutnya digunakan untuk membiayai upaya rehabilitasi serta pembersihan lahan dari kontaminasi limbah beracun. Perusahaan pencemar, jika diketahui, kemudian akan diminta pertanggungjawaban perdatanya untuk mengganti semua biaya yang telah digunakan oleh Pemerintah dalam upaya rehabilitasi lingkungan.

Beberapa jenis dana kompensasi yang telah dikemukakan oleh beberapa penulis dan telah berlaku di beberapa negara adalah sebagai berikut:

Lihat: M. Faure dan T. Hartlief, 2003, Policy Issues in Insurance: Insurance and Expanding Systemic Risks, (Organization for Economic Co-Operation and Development (OECD), 2003), hal. 148-151.

${ }^{24}$ Mereka yang tidak suka resiko akan berusaha untuk mengalihkan resiko kerugian tersebut kepada orang lain (penanggung), meskipun hal ini berarti bahwa orang tersebut akan kehilangan sejumlah kecil uang secara pasti dalam bentuk premi. Penjelasan mengenai penurunan utilitas serta bagaimana premi asuransi secara teoritis akan berhubungan dengan derajat ketidaksukaan terhadap resiko akan dijelaskan pada lampiran 2 dari tulisan ini. 


\section{- Guarantee Funds}

Dana ini digunakan ketika pencemar tidak memiliki cukup dana untuk membayar kompensasi. Hal ini misalnya terlihat dalam sistem yang dikembangkan melalui International Oil Pollution Compensation Fund. ${ }^{25}$ Penggunaan dana kompensasi ini harus didahului oleh adanya pertanggungjawaban perdata dari pencemar yang kemudian ternyata tidak mampu memenuhi pertanggungjawaban tersebut.

- Complementary and Autonomous Compensation Funds

Dana kompensasi dapat pula berupa pelengkap dari pertanggungjawaban perdata atau berupa dana yang independen terhadap pertanggungjawaban perdata. Dana kompensasi bersifat pelengkap apabila ia hanya dapat digunakan pada kasus di mana para korban gagal memperoleh kompensasi melalui sistem pertanggungjawaban perdata. Kegagalan ini biasanya muncul ketika pencemar dapat memberikan "alasan yang valid", yang dapat membebaskannya dari pertanggungjawaban perdata. Sistem ini dapat pula kita lihat di dalam International Oil Pollution Compensation Fund. ${ }^{26}$ Dengan demikian, dana kompensasi yang bersifat pelengkap juga harus didahului oleh proses peradilan perdata.

Sedangkan dana kompensasi bersifat independen dari pertanggungjawaban perdata apabila ia dapat digunakan tanpa memperhatikan apakah pihak korban dapat menggunakan peradilan perdata atau tidak. Dana ini digunakan terutama untuk pencemaran yang terjadi tanpa diketahui pihak penyebabnya, atau pencemaran yang terjadi karena adanya force majeure. Dana kompensasi ini dapat dilihat dalam Air Pollution Fund di Belanda atau dalam Offshore Oil Pollution Compensation Fund di AS. Di dalam dana kompensasi di Belanda dan AS ini, pihak korban memiliki pilihan apakah akan menggunakan jalur pengadilan (dengan jumlah kompensasi yang lebih besar, tapi terdapat kemungkinan kalah Cit., hal. 325.

${ }^{25}$ H. Bocken, 1988, Op. Cit., hal. 4. Lihat juga: M. Faure dan T. Hartlief, 1996, Op.

${ }^{26}$ H. Bocken, 1998, Op. Cit., hal. 4-5. 
dan proses yang panjang) atau menggunakan dana kompensasi (lebih pasti, tetapi biasanya dananya terbatas). ${ }^{27}$

- Limitation

Dana kompensasi ini digunakan bukan untuk melindungi korban, tetapi justru untuk melindungi para pencemar. Menurut sistem ini, pihak pencemar hanya akan bertanggungjawab sebesar dana yang dikumpulkannya di dalam fund. Dana ini dapat dilihat dalam pasal V 1969 Convention on Civil Liability for Oil Pollution Damage $(\mathrm{CLC}){ }^{28}$

- Advancement Fund

Dana ini dibayarkan oleh calon pencemar kepada calon korban di muka (sebelum terjadinya kerugian). Dana jenis ini muncul untuk kasus-kasus yang menyebabkan kematian, di mana waktu antara terjadinya pencemaran dengan kematian korban berlangsung singkat. Untuk kasus seperti ini, pertanggungjawaban perdata tidak akan efektif untuk melindungi korban, karena apabila proses pengadilan digunakan untuk mengganti kerugian korban, maka korban tersebut hanya akan menerima ganti kerugian setelah kematiannya (post mortem). Di Belanda, dana ini digunakan untuk kompensasi terhadap para korban asbestos. ${ }^{29}$

- General Compensation Systems

Di negara maju, sistem keamanan sosial dapat pula digunakan sebagai cara untuk memperoleh kompensasi. Bocken menyebutkan bahwa kompensasi yang dapat diperoleh dengan melalui sistem keamanan sosial terkait dengan kerugian karena penyakit, cacat, kecelakaan kerja, atau hilangnya pekerjaan. Meskipun korban dapat memperoleh kompensasi secara

${ }^{27}$ Ibid., hal. 5. Menurut penulis, dana restorasi (restoration fund) yang disebutkan oleh Faure dan Hartlief termasuk ke dalam kategori dana kompensasi ini, karena dana restorasi menurut para penulis itu adalah dana yang muncul ketika tidak ada kejelasan tentang sumber pencemar, dan karenanya tidak ada pihak yang dapat dimintakan pertanggungjawabannya. M. Faure dan T. Hartlief, 1996, Loc. Cit.

${ }^{28}$ M. Faure, 2004, Op. Cit., hal. 480.

${ }^{29}$ Ibid., hal. 481. Lihat pula: M. Faure dan T. Hartlief, 1996, Op. Cit., hal. 322. 
dan proses yang panjang) atau menggunakan dana kompensasi (lebih pasti, tetapi biasanya dananya terbatas). ${ }^{27}$

- Limitation

Dana kompensasi ini digunakan bukan untuk melindungi korban, tetapi justru untuk melindungi para pencemar. Menurut sistem ini, pihak pencemar hanya akan bertanggungjawab sebesar dana yang dikumpulkannya di dalam fund. Dana ini dapat dilihat dalam pasal V 1969 Convention on Civil Liability for Oil Pollution Damage $(\mathrm{CLC}){ }^{28}$

- Advancement Fund

Dana ini dibayarkan oleh calon pencemar kepada calon korban di muka (sebelum terjadinya kerugian). Dana jenis ini muncul untuk kasus-kasus yang menyebabkan kematian, di mana waktu antara terjadinya pencemaran dengan kematian korban berlangsung singkat. Untuk kasus seperti ini, pertanggungjawaban perdata tidak akan efektif untuk melindungi korban, karena apabila proses pengadilan digunakan untuk mengganti kerugian korban, maka korban tersebut hanya akan menerima ganti kerugian setelah kematiannya (post mortem). Di Belanda, dana ini digunakan untuk kompensasi terhadap para korban asbestos. ${ }^{29}$

- General Compensation Systems

Di negara maju, sistem keamanan sosial dapat pula digunakan sebagai cara untuk memperoleh kompensasi. Bocken menyebutkan bahwa kompensasi yang dapat diperoleh dengan melalui sistem keamanan sosial terkait dengan kerugian karena penyakit, cacat, kecelakaan kerja, atau hilangnya pekerjaan. Meskipun korban dapat memperoleh kompensasi secara

${ }^{27}$ Ibid., hal. 5. Menurut penulis, dana restorasi (restoration fund) yang disebutkan oleh Faure dan Hartlief termasuk ke dalam kategori dana kompensasi ini, karena dana restorasi menurut para penulis itu adalah dana yang muncul ketika tidak ada kejelasan tentang sumber pencemar, dan karenanya tidak ada pihak yang dapat dimintakan pertanggungjawabannya. M. Faure dan T. Hartlief, 1996, Loc. Cit.

${ }^{28}$ M. Faure, 2004, Op. Cit., hal. 480.

${ }^{29}$ Ibid., hal. 481. Lihat pula: M. Faure dan T. Hartlief, 1996, Op. Cit., hal. 322. 
lingkungan dan mengambil semua langkah pencegahan pencemaran. ${ }^{33}$ Di sisi lain, gugatan negara ini juga berfungsi untuk menghindari berubahnya kompensasi dan rehabilitasi yang dilakukan oleh Pemerintah menjadi semacam subsidi terselubung bagi para pencemar.

\section{Kompensasi di Indonesia}

Sistem pertanggungjawaban perdata yang ada di Indonesia sebenarnya sudah sejalan dengan Green Paper, karena berdasarkan undang-undang lingkungan hidup kita (UU No. 23/1997-UUPLH) pertanggungjawaban perdata dapat didasarkan pada perbuatan melawan hukum (pasal 34) ataupun pertanggungjawaban langsung (pasal 35). Meskipun demikian, hal ini tidak berarti kompensasi di Indonesia telah tersistem. Sebaliknya, mekanisme kompensasi menurut UUPLH justru sangat tergantung pada sistem pertanggungjawaban, tanpa ada satu pun pasal yang secara tegas menggambarkan alternatif kompensasi apabila sistem pertanggungjawaban tidak berfungsi.

Memang penjelasan pasal 35 ayat 1 UUPLH telah membuka kemungkinan diterapkannya asuransi tanggung jawab wajib dengan mengatakan bahwa:

“...Besarnya nilai ganti rugi yang dapat dibebankan terhadap pencemar atau perusak lingkungan hidup menurut Pasal ini dapat ditetapkan sampai batas waktu tertentu. Yang dimaksud sampai batas waktu tertentu, adalah jika menurut penetapan peraturan perundang-undangan yang berlaku, ditentukan keharusan asuransi bagi usaha dan/atau kegiatan yang bersangkutan atau telah tersedia dana lingkungan hidup -(kursif dari penulis) ". ${ }^{34}$

Namun demikian, penjelasan di atas masih sangat minim. Yang jelas, sampai saat ini tidak ada satu pun peraturan pelaksanaan UUPLH yang mengatur mengenai asuransi tanggung jawab wajib. Di samping itu, seperti telah dikemukakan sebelumnya, asuransi tanggung jawab sebenarnya masih termasuk ke dalam lapis pertama dari sistem

${ }^{33}$ M. Faure, 2007b, "Financial Compensation for Victims of Catastrophes: A Law and Economics Perspective", Law and Policy, Vol. 29, No. 3, hal. 354-355.

${ }^{34}$ Mengingat bahwa pernyataan tentang asuransi ini dimasukkan ke dalam penjelasan mengenai pertanggungjawaban berdasarkan strict liability maka dapat disimpulkan bahwa asuransi yang dikenal oleh UUPLH adalah asuransi tanggung jawab. 
kompensasi. Lebih jauh lagi, UUPLH gagal untuk mendefinisikan alternatif kompensasi lainnya, seperti asuransi kerugian lingkungan atau dana kompensasi.

Di samping berdasarkan UUPLH, sistem kompensasi lingkungan Indonesia juga dapat merujuk pada UU Penganggulangan Bencana (UU No. 24 tahun 2007) dan PP No. 22 tahun 2008 tentang pendanaan dan pengelolaan bantuan bencana, karena "bencana" menurut UU ini tidak hanya meliputi bencana alam, tetapi juga man-made disaster, yang di dalamnya tentu saja termasuk bencana karena pencemaran lingkungan. ${ }^{35}$ Menurut sistem ini, kompensasi digolongkan sebagai "bantuan" yang sepertinya muncul lebih karena solidaritas, dan bukan karena pertanggungjawaban hukum. Berdasarkan sistem ini, kompensasi diberikan oleh negara (melalui penggunaan dana APBN atau APBD) atau melalui bantuan/sumbangan.

Kompensasi menurut UU Pengelolaan Bencana dapat digolongkan ke dalam kategori "direct compensation" seperti yang telah dikemukakan sebelumnya. Kami berpendapat bahwa kompensasi oleh negara untuk kasus pencemaran lingkungan bukanlah merupakan sebuah kesalahan, apalagi untuk kasus-kasus pencemaran yang sangat serius dan memerlukan penanganan sesegera mungkin. Yang keliru dari kompensasi bencana menurut UU Pengelolaan Bencana adalah absennya langkah hukum yang harus ditempuh oleh Pemerintah terhadap pihak yang diduga sebagai penyebab terjadinya bencana/ pencemaran. Ini berarti bahwa mekanisme kompensasi menurut UU Pengelolaan Bencana di satu sisi memberikan jaminan bahwa korban akan memperoleh bantuan secara relatif cepat (karena tidak membutuhkan proses peradilan), namun di sisi lain mekanisme ini justru membuka peluang terjadinya subsidi terselubung bagi para pencemar.

Untuk menghindari pelanggaran atas asas pencemar membayar ini, selayaknya kompensasi langsung oleh negara segera disusul dengan adanya penggunaan hak gugat pemerintah seperti diatur dalam pasal 37 ayat 2 UUPLH. Dalam hal ini, gugatan oleh pemerintah dimaksudkan untuk meminta pencemar mengganti semua biaya yang telah dikeluarkan oleh Pemerintah dalam upaya pembayaran kompensasi dan penanggulangan serta pemulihan dampak bencana lingkungan yang terjadi. ${ }^{36}$

${ }^{35}$ Pasal 1 UU No. 24 tahun 2007. 


\section{A. Asuransi Lingkungan di Indonesia}

Seperti diutarakan pada bagian sebelumnya, asuransi lingkungan di Indonesia sampai saat ini hanya didasarkan pada penjelasan pasal 35 UUPLH, yang membuka kemungkinan diadakannya pembatasan pertanggungjawaban perdata apabila di Indonesia sudah berlaku asuransi lingkungan wajib. Mengingat sampai dengan saat ini tidak ada peraturan mengenai asuransi wajib di Indonesia, ${ }^{37}$ maka menjadi menarik untuk melihat bagaimana asuransi lingkungan dipraktekkan di Indonesia.

\section{Praktek Asuransi lingkungan di Indonesia}

Di Indonesia sendiri asuransi lingkungan adalah merupakan produk asuransi yang masih bisa dikatakan relatif baru. Hal ini dapat dilihat dati ketersediaan produk asuransi lingkungan di pasar asuransi Indonesia yang masih relatif kecil.

Di antara sekian banyak perusahaan asuransi di Indonesia, hanya beberapa perusahaan saja yang telah memasarkan asuransi lingkungan sebagai produk mereka. Di antara perusahan tersebut yang berhasil kami catat adalah Ai Insurance dan Ac Insurance. Adapun jenis pertanggungan yang ditawarkan oleh masingmasing perusahaan adalah sebagai berikut:

I. PT Ac: Premise Pollution Liability II Insurance Policy

Polis asuransi lingkungan yang dikeluarkan oleh PT. ACE

INA Insurance berbasis claim made policy, yang berarti bahwa polis akan memberikan ganti rugi kepada tertanggung atas gugatan yang diajukan kepadanya selama periode

${ }^{36}$ Dengan demikian, maka gugatan pemerintah ini memiliki alasan yang lebih kuat dari pada alasan yang disebutkan dalam pasal 37 (2) UUPLH. Pasal ini menjelaskan bahwa gugatan pemerintah dilakukan "Jika diketahui bahwa masyarakat menderita karena akibat pencemaran dan/atau perusakan lingkungan hidup sedemikian rupa sehingga mempengaruhi perikehidupan pokok masyarakat..." Pasal ini tidak menjelaskan bagaimana pemerintah mengelola uang ganti kerugian (jika gugatannya dikabulkan). Artinya pasal ini tidak memberikan jaminan bahwa uang ganti kerugian akan sampai pada masyarakat korban. Karena itu, dengan hanya menggugat untuk meminta uang penggantian, maka ketidakjelasan tersebut dapat diatasi.

${ }^{37}$ Asuransi tanggung jawab yang terkait dengan lingkungan hidup tidak diturunkan dari UUPLH, tetapi dari Civil Liability Convention (1969) tentang pertanggungjawaban atas pencemaran laut oleh kapal tanker, dan UU No. 10 tahun 1997 tentang ketenaganukliran. Artinya, di luar kedua jenis usaha/kegiatan ini, pelaku usaha/kegiatan tidak diwajibkan untuk memiliki asuransi tanggung jawab lingkungan. 
asuransi berlangsung. ${ }^{38}$ Terdapat dua kondisi jaminan yang ditanggung dalam polis ini, yaitu: ${ }^{39}$

A. Kondisi Pencemaran Baru (New Polltuion Conditions)

Polis ini memberikan jaminan ganti kerugian atas setiap tuntutan dimana tertanggung dinyatakan bertanggung jawab secara hukum atas cidera badan (luka badan, cacat badan atau kematian), kerugian harta benda pihak ketiga atau biaya pembersihan lingkungan akibat kondisi pencemaran baik didalam obyek pertanggungan, maupun diluar obyek pertanggungan yang terjadi akibat kesalahan dan/atau kelalaian tertanggung, serta kondisi pencemaran yang terjadi selama proses pemindahan limbah dari lokasi yang dipertanggungkan ke lokasi pembuangan/pengolahan limbah. Selain itu polis ini juga memberikan jaminan ganti kerugian atas setiap biaya pembelaan hukum.

Pertanggungan yang diberikan hanya berlaku bagi kondisi pencemaran yang terjadi pada saat atau setelah tanggal mulai berlaku polis ini.

B. Kondisi Sebelum Terjadinya Pencemaran (Pre-Exisiting Pollution Conditions)

Polis ini memberikan jaminan ganti kerugian atas setiap tuntutan dimana tertanggung dinyatakan bertanggung jawab secara hukum atas cidera badan (luka badan, cacat badan atau kematian), kerugian harta benda pihak ketiga atau biaya pembersihan lingkungan akibat kondisi pencemaran baik didalam obyek pertanggungan, maupun diluar obyek pertanggungan yang terjadi akibat kesalahan dan/atau kelalaian tertanggung, serta kondisi pencemaran yang terjadi selama proses pemindahan limbah dari lokasi yang dipertanggungkan ke lokasi pembuangan/pengolahan limbah. Selain itu polis ini

38 Reasuransi Nasional Indonesia, "Technical Liability Insurance Workshop: Focusing on Professional Indemnity, Product Liability and CGL," (Makalah disampaikan pada lokakarya Technical Liability Insurance Workshop, Jakarta 27 \& 28 April 2009), hal $10 / 3$.

39 Data berdasarkan polis Premise Pollution Liability II Insurance Policy yang dikeluarkan oleh PT. Ac Insurance. 
juga memberikan jaminan ganti kerugian atas setiap biaya pembelaan hukum.

Pertanggungan yang diberikan hanya berlaku bagi kondisi pencemaran yang terjadi sebelum tanggal mulai berlaku polis ini.

\section{PT Ai Indonesia}

Terdapat dua macam polis asuransi lingkungan dengan basis claim made policy yang dikeluarkan oleh PT. Ai Indonesia, yaitu: ${ }^{40}$

A. Polis Pertanggungjawaban Hukum Pencemaran (Pollution Legal liability Policy)

$\mathrm{Di}$ dalam polis ini terdapat sepuluh macam pertanggungan yang dijamin,yang secara garis besar dapat dikelompokkan menjadi tiga macam, yaitu:

(a).Kondisi Pencemaran Baru (New Pollution Conditions)

Polis ini memberikan jaminan ganti kerugian atas setiap tuntutan dimana tertanggung dinyatakan bertanggung jawab secara hukum atas cidera badan (luka badan, cacat badan atau kematian), kerugian harta benda pihak ketiga atau biaya pembersihan lingkungan akibat kondisi pencemaran baik didalam obyek pertanggungan, maupun diluar obyek pertanggungan yang terjadi akibat kesalahan dan/atau kelalaian tertanggung, serta kondisi pencemaran yang terjadi selama proses pemindahan limbah dari lokasi yang dipertanggungkan ke lokasi pembuangan/pengolahan limbah. Selain itu polis ini juga memberikan jaminan ganti kerugian atas setiap biaya pembelaan hukum.

Pertanggungan yang diberikan hanya berlaku bagi kondisi pencemaran yang terjadi pada saat atau setelah tanggal mulai berlaku polis ini.

(b).Kondisi Sebelum Terjadi Pencemaran (Pre-Exisiting Conditions)

${ }^{40}$ Data berdasarkan polis Pollution Legal Liability Policy dan Contractor's Pollution Liability Policy yang dikeluarkan oleh PT. Ai. 
Polis ini memberikan jaminan ganti kerugian atas setiap tuntutan dimana tertanggung dinyatakan bertanggung jawab secara hukum atas cidera badan (luka badan, cacat badan atau kematian), kerugian harta benda pihak ketiga atau biaya pembersihan lingkungan akibat kondisi pencemaran baik didalam obyek pertanggungan, maupun diluar obyek pertanggungan yang terjadi akibat kesalahan dan/ atau kelalaian tertanggung, serta kondisi pencemaran yang terjadi selama proses pemindahan limbah dari lokasi yang dipertanggungkan ke lokasi pembuangan/pengolahan limbah. Selain itu polis ini juga memberikan jaminan ganti kerugian atas setiap biaya pembelaan hukum.

Pertanggungan yang diberikan hanya berlaku bagi kondisi pencemaran yang terjadi sebelum tanggal mulai berlaku polis ini.

(c). Pertanggungan terhadap gangguan bisnis berupa kehilangan keuntungan atau nilai sewa dan biaya tambahan lain (business interruption coverage profit loss or rental value and extra expenses).

Polis ini memberikan jaminan ganti kerugian atas setiap kerugian berupa kehilangan keuntungan atau kehilangan uang sewa, serta biaya tambahan lain akibat kondisi pencemaran yang terjadi didalam obyek pertanggungan, maupun diluar obyek pertanggungan.

B. Polis Pertanggungjawaban Kontraktor terhadap Pencemaran (Contractor's Pollution Liability Policy)

Polis ini akan memberikan jaminan ganti kerugian untuk setiap tuntutan dimana tertanggung dinyatakan bertanggung jawab secara hukum atas cidera badan (luka badan, cacat badan atau kematian), kerugian harta benda pihak ketiga atau biaya pembersihan lingkungan akibat kondisi pencemaran (merupakan kejadian yang tidak diharapkan atau tidak disengaja) yang terjadi dari aktivitas tertanggung yang dijamin dalam polis. Selain itu polis ini juga memberikan jaminan ganti kerugian atas setiap biaya pembelaan hukum. 
Berdasarkan data diatas, dapat disimpulkan bahwa, meskipun secara teoritis terdapat tiga macam bentuk jaminan asuransi lingkungan, akan tetapi pada prakteknya di Indonesia jaminan asuransi lingkungan masih terbatas pada jenis asuransi tanggung jawab hukum lingkungan saja (Third Party Insurace).

\section{III.A. Asuransi Tanggung Jawab Hukum Lingkungan Sebagai Asuransi Wajib}

Penyelenggaran asuransi tanggung jawab hukum sebagai asuransi wajib bertujuan untuk melindungi hak-hak pihak ketiga (korban). Karena dengan terdapatnya kewajiban bagi pengusaha/perusahaan (pihak yang berpotensi mengakibatkan kerugian) untuk memiliki asuransi, maka korban dapat terhindar dari kemungkinan terjadinya insolvency pencemar yang dapat mengakibatkan terjadinya pelanggaran hak korban dalam hal ganti rugi. ${ }^{41}$

Selain pembenaran pemberlakuan asuransi di atas, masih terdapat beberapa pembenaran lainnya, yaitu untuk mengatasi persoalan informasi (information problem). Information problem terjadi apabila pihak yang berpotensi mengakibatkan kerugian tidak dapat melakukan penilaian secara baik tentang tingkat resiko yang dihadapinya dan tentang manfaat yang akan didapatkan dengan membeli asuransi. Dalam hal ini, ketidakmampuan melakukan penilaian atas resiko muncul karena kurangnya informasi yang tersedia tentang tingkat resiko yang dihadapi. Penilaian yang terlalu rendah terhadap suatu resiko, akan berpengaruh terhadap pengambilan keputusan untuk tidak membeli asuransi. Pada umumnya pihak yang berpotensi mengakibatkan kerugian lebih sering meremehkan biaya akibat kerusakan suatu resiko, dan besarnya kemunginan untuk bertanggung jawab atas kerusakan tersebut. Hal ini dapat menyebabkan tidak adanya insentif bagi pihak tersebut untuk menyediakan dana cadangan apabila ia diharuskan untuk bertanggung jawab atas kerugian yang disebabkannya.

${ }^{41}$ Faure dan Hartlief menambahkan bahwa dalam perspektif analisa ekonomi atas hukum (law and economics) pemberlakuan asuransi tanggung jawab hukum bertujuan untuk meningkatkan kondisi utilitas pencemar yang risk averse. M. Faure dan T. Hartlief, 2003, Op. cit., hal. 211. Menurut kami, dari perspektif law and economics, asuransi tanggung jawab ini terutama bermanfaat sebagai pencegahan insolvency. Singkatnya, yang risk averse terhadap keadaan insolvency adalah calon korban (masyarakat atau negara), sehingga dalam kenyataannya asuransi tanggung jawab ini muncul dari adanya sebuah kewajiban yang terjadi karena desakan masyarakat atau negara. Memang benar bahwa asuransi pada prinsipnya terkait dengan penurunan utility sebagai adanya resiko kerugian. Tetapi menurut hemat kami, keberadaan asuransi sebagai akibat adanya penurunan utility ini terutama sekali terlihat pada asuransi kerugian (first party insurance), dan bukan asuransi tanggung jawab (third party insurance). Lihat Lampiran 1 tulisan ini. 
Hal lain yang dapat dijadikan pembenaran dari pemberlakuan suatu asuransi wajib dapat dilihat melalui perspektif behavioural law and economics tentang heuristics. Yang dimaksud dengan heuristic adalah pengambilan keputusan individu (pelaku usaha) berdasarkan penilaian subyektif terhadap probabilitas suatu resiko yang lebih didasarkan pada intuisi atau pemberitaan dan bukan pada pengamatan. Meskipun terkadang pengambilan keputusan tersebut dapat memberikan jawaban yang benar, akan tetapi tidak jarang juga hal tersebut menyebabkan pengambilan keputusan yang keliru. ${ }^{42}$

Dalam hal pelaku usaha dihadapkan pada suatu resiko yang memiliki potensi kerugian besar, dengan tingkat probabilitas yang kecil untuk terjadi, maka akan mengakibatkan pelaku usaha tersebut telalu optimis dalam mengambil keputusan (overconfidence). Dalam kaitannya dengan asuransi, keadaan tersebut akan berdampak terhadap pengambilan keputusan oleh pelaku usaha untuk tidak membeli asuransi karena ia terlalu optimis bahwa ia tidak akan mengalami kerugian. Jika ternyata perkiraan pelaku usaha tersebut salah (resiko terjadi) dan mengakibatkan kerugian yang sangat besar, maka akan terjadi undercompensation dan externalization through insolvency.

\section{III.B. Permasalahan dalam Asuransi Lingkungan Wajib}

Seperti dikemukakan pada bagian terdahulu, moral hazard merupakan permasalahan yang harus diatasi oleh industri asuransi. Apabila kontrol terhadap moral hazard sulit untuk dilakukan dan memakan biaya yang sangat besar, maka kemungkinan pemberlakuan asuransi wajib akan menjadi masalah. Dalam asuransi yang bersifat sukarela ada beberapa cara yang diterapkan oleh penanggung untuk mengontrol moral hazard. Salah satunya adalah melalui metode deductible. ${ }^{43}$ Melalui penerapan deductible tertanggung diwajibkan untuk meretensi sebagian resiko yang dihadapinya.

42 M. Faure dan A.G. Wibisana, 2007, "Behavioral Law and Economics: The Consequences for economic Models of Liability and Insurance", (Makalah disampaikan pada lokakarya Searcing for New Models in The Economic Analysis of Law, Univerisity of Messina, Italia, 25-27 Maret 2007, hal 9

${ }^{43}$ M. Faure dan D. Grimeaud, 2003, Op. Cit., hal.185. Di samping deductible, persoalan moral hazard dapat pula diatasi dengan jalan diberlakukannya perjanjian kerugian (loss-sharing) antara penanggung dan tertanggung, experience rating (modifikasi premi berdasarkan kerugian yang diderita tertanggung), premium credits or surcharges (premi tambahan yang ditentukan berdasarkan pengamatan terhadap tingkat kehati-hatian tertanggung), dan pengamatan terhadap klaim kerugian. S.E. Harrington, 2000, "Rethinking Disaster Policy", Regulation, Vol. 23, No. 1, hal. 41. 
Hal ini akan memberikan insentif bagi tertanggung untuk menjalankan kegiatannya dengan hati-hati agar menghindari terjadinya kecelakaan.

Permasalahan lain yang juga harus diperhatikan dalam pemberlakuan asuransi wajib adalah masalah ketersediaan (supply) di pasar asuransi. Sebagaimana diketahui, asuransi tanggung jawab lingkungan merupakan jenis asuransi yang masih baru dan memerlukan waktu yang bertahap agar dapat berkembang. Terbatasnya ketersediaan asuransi tanggung jawab hukum lingkungan lebih banyak disebabkan oleh permasalahan adverse selection atau sedikitnya permintaan atas asuuransi tanggung jawab lingkungan sehingga menyebabkan diversifikasi resiko menjadi tidak optimal. ${ }^{44}$

Selain hal tersebut, permintaan atas asuransi tanggung jawab lingkungan juga lebih banyak berasal dari pelaku usaha yang memiliki resiko tinggi (hal ini juga merupakan faktor penyebab terjadinya permasalahan adverse selection). Oleh karena itu pemberlakuan asuransi wajib bagi para pelaku usaha untuk mengatasi permasalahan terbatasnya ketersediaan asuransi tanggung jawab lingkungan merupakan suatu keputusan yang tidak logis.

Permasalahan terakhir yang juga harus diperhatikan dalam pemberlakuan asuransi wajib, adalah permasalahan duty to accept. Dalam hal industri asuransi menolak untuk menyediakan jaminan yang dibutuhkan, maka pemerintah biasanya tidak hanya memberikan kewajiban bagi pelaku usaha untuk memiliki asuransi, akan tetapi juga mewajibkan perusahaan asuransi untuk melakukan akseptasi. Akan tetapi pemberlakuan duty to accept bagi industri asuransi tertentu sebagai tertaggung adalah merupakan langkah yang berbahaya, karena dapat menyebabkan moral hazard menjadi tidak terkontrol.

Salah satu instrumen yang dapat digunakan penanggung untuk mengontol moral hazard ialah dengan memiliki kemungkinan untuk memonitor ex-ante resiko-resiko yang mungkin dihadapi tertanggung. Akan tetapi jika terdapatnya kewajiban bagi penanggung untuk mengakseptasi resiko tanpa melalui proses underwriting, maka dapat mengakibatkan penanggung mengakseptasi resiko yang terlalu besar.

Sebagaimana diketahui bahwa agar pengawasan moral hazard dapat optimal, maka penanggung harus diberi kebebasan untuk memilih pihakpihak yang akan ditanggugnya. Oleh karena itu pemberlakuan duty to accept adalah merupakan tindakan yang bertolak belakang dengan prinsip dasar yang harus dipenuhi agar pasar asuransi dapat berfungsi dengan baik. ${ }^{45}$

${ }^{44}$ M. Faure dan D. Grimeaud, 2003, Op. Cit., hal. 188-189. 


\section{III.C. Kesiapan Perusahaan Asuransi dalam Penyelenggaraan Asuransi Wajib Lingkungan}

Berdasarkan wawancara dengan dua perusahaan asuransi yang sudah menyediakan jaminan pertanggungjawaban pencemaran diketahui bahwa mereka mampu menyediakan kapasitas nilai pertanggungan yang cukup besar. Selain itu para penanggung juga meyakini bahwa potensi liability mereka tidak akan mencapai skala katastropik karena tidak mungkin kerusakan pada lingkungan terjadi secara bersamaan. Ditambah lagi dengan mereka menggunakan jenis polis claim made-based sehingga seluruh gugatan tidak mungkin terjadi pada satu periode asuransi saja. Kombinasi dari ketiga faktor itu juga membuat mereka menganggap tidak perlu dibentuk suatu sistem risk pooling atau risk sharing antara sesama penanggung unțuk mengantisipasi terhadap akumulasi resiko.

Bahkan responden ${ }^{46}$ menyambut baik apabila asuransi tanggung jawab diwajibkan. Hal ini dikarenakan masih sedikitnya perusahaan asuransi yang dapat memberikan jaminan pertanggungjawaban pencemaran di Indonesia. Sehingga apabila diwajibkan maka mereka dapat mendominasi pasar asuransi.

Namun responden juga memberikan beberapa catatan apabila resiko ini hendak dimasukkan ke dalam skema asuransi lingkungan wajib. Pertama, mereka meminta agar penegakan hukum lingkungan di Indonesia, khususnya pada pelaku usaha yang diwajibkan nantinya untuk membeli asuransi, agar lebih dipertegas. Tujuannya adalah agar pelaku usaha yang telah mematuhi peraturan perundangan hukum lingkungan secara aktual memiliki tingkat resiko yang rendah dalam pencemaran lingkungan. Responden tidak secara spesifik memberikan contoh-contoh standar penegakan hukum lingkungan, namun mereka berpendapat bahwa standar yang ada saat ini masih kurang memadai. ${ }^{47}$

Catatan kedua yang disampaikan oleh responden adalah mereka menolak pengaturan duty to accept dalam asuransi wajib ini nantinya.

${ }^{45}$ Ibid., hal. 189.

${ }^{46}$ Hasil Wawancara dengan Underwriter ACE Insurance pada tanggal 19 Juni 2009 , dan hasil wawancara dengan Head Liabilities AIU Insurance pada tanggal 22 Juni 2008.

47 Pendapat ini sejalan dengan pendapat Faure, yang menyatakan bahwa ketidaksukaan pihak asuransi terhadap asuransi tanggung jawab hukum adalah karena dalam asuransi tanggung jawab hukum penanggung menanggung resiko kemungkinan tertanggung dinyatakan bertanggung jawab atas kerugian pihak ketiga (dimana lokasi obyek pertanggungan masih belum pasti). Selain itu ketidaksukaan pihak asuransi terhadap asuransi tanggung jawab hukum juga dikarenakan terdapatnya ketidakpastian di dalam asuransi tanggung jawab hukum (dimana resiko tertanggung untuk dinyatakan bertanggung jawab adalah tergantung dari interpretasi hakim). M. Faure dan T. Hartlief, 2003, Op. Cit., hal. 149. 
Menurut responden, kesepakatan antara penanggung dan tertanggung merupakan murni negosiasi pra-kontrak antara penanggung dengan tertanggung. Sehingga walaupun tertanggung diwajibkan memiliki asuransi tersebut, namun penanggung tetap bebas dalam memutuskan akseptasi terhadap resiko yang ditawarkan tertanggung. Hal ini memberikan insentif bagi tertanggung untuk melakukan segala kehati-hatian untuk mencegah pencemaran. Apabila tertanggung mempunyai resiko yang buruk di mata penanggung, maka tertanggung bisa tidak mendapat jaminan asuransi yang diwajibkan oleh undang-undang dan dapat terkena sanksi dari regulator atau reputasi yang buruk dari mitra usahanya.

Berdasarkan penjelasan-penjelasan diatas, maka dapat disimpulkan bahwa meskipun di satu sisi terdapat beberapa permasalahan yang dihadapi dalam pemberlakuan asuransi wajib lingkungan, akan tetapi tidak dapat dipungkiri bahwa di sisi lain, pemberlakuan asuransi wajib lingkungan juga memberikan manfaat tidak hanya bagi korban secara khusus, akan tetapi juga bagi masyarakat secara umum. Oleh karena itu pemerintah sebaiknya mempertimbangkan pemberlakuan asuransi wajib lingkungan sebagai salah satu alternatif pembiayaan dalam mengatasi permasalahan yang timbul dari pencemaran/kerusakan lingkungan.

\section{Kesimpulan}

Sistem kompensasi yang ideal adalah sebuah sistem berlapis, yang setidaknya memuat alternatif pertanggungjawaban perdata (dan asuransi pertanggungjawaban), asuransi kerugian lingkungan, serta dana kompensasi. Di samping bertujuan untuk memberikan perlindungan bagi para korban pencemaran, sistem kompensasi juga harus mampu mendorong terjadinya internalisasi biaya lingkungan, dan karenanya sistem ini sama sekali tidak boleh melanggar asas pencemar membayar.

Sistem kompensasi di Indonesia menurut UUPLH dan UU Penanggulangan Bencana tampaknya masih jauh dari sistem yang ideal, bahkan tanpa sistem sama sekali. Mekanisme kompensasi kita masih menjadikan pertanggungjawaban perdata sebagai satu-satunya cara untuk memperoleh kompensasi. Korban menjadi tidak memiliki pilihan lain untuk memperoleh kompensasi kecuali dengan mengajukan gugatan perdata. Di samping itu, pertanggungjawaban perdata tidak disertai dengan adanya asuransi tanggung jawab wajib, sehingga bahkan jika korban dapat memenangkan gugatannya, masih terdapat kemungkinan mereka tidak akan memperoleh kompensasi jika aset pencemar ternyata kurang dari kerugian yang diderita oleh korban. 
Dengan tidak adanya kewajiban untuk memiliki asuransi tanggung jawab, maka asuransi tanggung jawab menjadi tidak berkembang. Penelitian ini menunjukkan bahwa meskipun pasar asuransi tanggung jawab telah tersedia, namun hanya sedikit saja dari perusahaan yang mau mengikuti program asuransi tanggung jawab atas usaha/kegiatannya. Dengan kata lain, di Indonesia kegiatan/usaha yang beresiko tinggi tetap diizinkan untuk beroperasi, meskipun penanggungjawab kegiatan/usaha ini sebenarnya belum tentu memiliki jaminan keuangan yang cukup untuk membayar semua kerugian yang muncul.

Lapis pertama mekanisme kompensasi yang tidak sempurna ternyata disertai pula dengan tidak adanya lapis kedua sebagai alternatif bagi pertanggungjawaban dan asuransi tanggung jawab. Dalam hal ini, penelitian ini menunjukkan bahwa asuransi kerugian (first party insurance) untuk pencemaran lingkungan belum berkembang. Tidak ditemukan pula adanya perusahaan asuransi yang menyediakan asuransi kerugian lingkungan seperti di Belanda. Meskipun secara teoritis terdapat tiga macam bentuk asuransi lingkungan, akan tetapi dalam prakteknya jenis asuransi lingkungan yang sampai saat ini berkembang di Indonesia masih terbatas pada asuransi tanggung jawab hukum lingkungan (third party/liability insurance).

Ketidaksempurnaan sistem kompensasi kita menjadi semakin terlihat dengan tidak tersistemnya dana kompensasi. Di Indonesia tidak ada pungutan yang secara khusus ditujukan untuk pendanaan kompensasi. Satu-satunya mekanisme dana kompensasi yang tersedia adalah kompensasi langsung oleh negara (berdasarkan UU Pengelolaan Bencana), yang sebenarnya justru merupakan pilihan terakhir dari beberapa alternatif pendanaan kompensasi. Lebih parahnya lagi, kompensasi langsung ini sama tidak dikaitkan dengan hak gugat negara, sehingga dapat dikatakan bahwa dalam kasus bencana lingkungan kompensasi langsung oleh negara ini berfungsi lebih sebagai subsidi terselubung terhadap para pencemar dan bukan sebagai mekanisme perlindungan negara terhadap warga negaranya.

Akibat dari tidak tersistemnya kompensasi di Indonesia terlihat jelas di dalam bencana lumpur Sidoarjo. Sampai saat ini, tidak ada satu pun korban lumpur Sidoarjo yang bersedia mengajukan gugatannya terhadap Lapindo, atau pihak lain yang dianggap bertanggung jawab atas bencana lumpur tersebut. Hal ini patut disayangkan mengingat secara hukum hanya dengan cara gugatan inilah para korban dapat memperoleh kompensasi yang memadai.

Campur tangan pemerintah dalam kasus ini pun dapat dikatakan sangat jauh dari efektif. Satu-satunya langkah hukum yang ditempuh oleh pemerintah adalah dengan mengeluarkan Peraturan Presiden No. 14 tahun 2007, yang kemudian diubah dengan Perpres No. 48 tahun 2008. Kedua 
Perpres ini di satu sisi mengizinkan penggunaan dana publik (APBN) untuk penanganan bencana lumpur (termasuk untuk membayar ganti kerugian bagi para korban), sedang di sisi lain memerintahkan Lapindo untuk melakukan pembelian atas rumah atau tanah di beberapa desa tertentu yang terkena dampak bencana lumpur.

Meskipun dalam beberapa kesempatan Pemerintah menyatakan bahwa Perpres tersebut adalah cara terbaik yang bisa mereka lakukan untuk melindungi korban, namun kedua Perpres ini patut dikritisi karena berbagai alasan. Pertama, yang diciptakan oleh Perpres ini sebenarnya bukanlah mekanisme kompensasi, tetapi jual beli, karena menurut Perpres ini pembayaran uang terhadap para korban akan disusul dengan pengalihan hak milik atas rumah atau tanah dari para korban kepada Lapindo atau Pemerintah. Karena yang diciptakan adalah mekanisme jual beli, maka tentu saja kerugian berupa penurunan kualitas hidup, hilangnnya pekerjaan, apalagi kerugian berupa kerusakan lingkungan menjadi tidak terkompensasi.

Kedua, kompensasi ini hanya terbatas pada beberapa desa terdampak yang ditentukan di dalam Perpres. Kompensasi bagi para korban di luar area tersebut sama sekali tidak diprogramkan. Sayangnya, ada kemungkinan yang cukup besar bahwa korban akan terus bertambah mengingat sampai saat ini luapan lumpur terus terjadi tanpa ada tanda-tanda berhenti.

Ketiga, dengan menggunakan dana publik tanpa disertai gugatan pemerintah untuk meminta penggantian, Pemerintah sebenarnya telah melakukan subsidi terselubung pada Lapindo atau pihak lain yang harus bertanggung jawab atas bencana lumpur ini. Dengan demikian, Pemerintah sebenarnya telah melakukan pelanggaran atas Asas Pencemar Membayar.

Terakhir, perintah Pemerintah terhadap Lapindo untuk melakukan pembelian rumah atau lahan yang terkena dampak sebenarnya tanpa disertai logika hukum yang jelas. Atas dasar apa Pemerintah memaksa Lapindo melakukan pembelian tersebut, sedangkan Lapindo sendiri masih bersikukuh bahwa bencana lumpur ini disebabkan oleh bencana alam gempa bumi? ${ }^{48}$ Ketiadaan alasan kuat inilah, ditambah dengan absennya sikap tegas Pemerintah, yang menurut penulis telah menjadi sebab mengapa pelaksanaan skema kompensasi menurut Perpres ini berjalan sangat tidak efektif dan lamban.

48 Pendapat Lapindo ini secara hukum diperkuat oleh Putusan PN Jaksel No. 284/Pdt.G/2007/PN.Jak.Sel., yang diperkuat dengan putusan PT Jakarka No. 383/PDT/2008/PT.DKI dalam perkara antara Walhi melawan PT. Lapindo Brantas, dkk. Dalam putusan tersebut, hakim berpendapat bahwa lumpur Sidoarjo disebabkan oleh bencana alam. Terlepas dari kejanggalan-kejanggalan logika dan pertimbangan yang lemah dalam putusan ini, yang pasti sampai dengan saat ini secara hukum Lapindo Brantas belum dinyatakan bertanggung jawab atas bencena lumpur Sidoarjo. 


\section{Epilog: Reformasi Sistem Kompensasi Lingkungan di Indonesia}

Kelemahan mekanisme kompensasi lingkungan di Indonesia sepertinya telah disadari oleh banyak kalangan. Hal ini terbukti dari adanya dicantumkannya berbagai pilihan kompensasi di dalam UUPPLH sebagai revisi atas mekanisme kompensasi UUPLH. Di luar sistem pertanggung jawaban perdata, UUPPLH telah memperkenalkan berbagai instrumen kompensasi.

Pasal 42 ayat 1 UUPPLH menyatakan bahwa: “...Pemerintah dan pemerintah daerah wajib mengembangkan dan menerapkan instrumen ekonomi lingkungan hidup". Sedangkan pasal 42 ayat 2 UUPPLH menyatakan bahwa: instrumen ekonomi tersebut meliputi berbagai instrumen untuk:

a. perencanaan pembangunan dan kegiatan ekonomi;

b. pendanaan lingkungan hidup; dan

c. insentif dan/atau disinsentif.

Selanjutnya di dalam pasal 43 ayat 2 dinyatakan bahwa bentuk instrumen pendanaan lingkungan hidup meliputi dana jaminan pemulihan lingkungan hidup, dana penanggulangan pencemaran dan/atau kerusakan dan pemulihan lingkungan hidup, serta dana amanah/bantuan untuk konservasi. Dalam penjelasan ayat ini diterangkan bahwa dana jaminan pemulihan adalah "dana yang disiapkan oleh suatu usaha dan/atau kegiatan untuk pemulihan kualitas lingkungan yang rusak karena kegiatannya"; sedangkan dana penanggulangan adalah "dana yang digunakan untuk menanggulangi pencemaran dan/atau kerusakan lingkungan hidup yang timbul akibat suatu usaha dan/atau kegiatan".

Di samping itu, Pasal 43 ayat 3 UUPPLH juga memperkenal asuransi lingkungan sebagai salah satu instrumen insentif/disinsentif. Di dalam penjelasan ayat ini dinyatakan bahwa asuransi lingkungan adalah: "asuransi yang memberikan perlindungan pada saat terjadi pencemaran dan/atau kerusakan lingkungan". Karena UUPPLH tidak menjelaskan apakah asuransi yang dimaksud berupa asuransi pihak pertama, asuransi pihak ketiga, ataukah asuransi kerugian lingkungan, maka peraturan pelaksanaan tentang asuransi lingkungan mau tidak mau harus menjelaskan secara lebih mendalam apa yang dimaksud dengan asuransi lingkungan (termasuk penjelasan mengenai siapa yang harus membayar premi, bagaimana penentuan premi, siapa yang diwajibkan memiliki asuransi tersebut, siapa yang akan menerima perlindungan asuransi, dan dengan cara apa kompensasi akan dibayarkan kepada korban). 
Perlu pula dinyatakan di sini bahwa UUPPLH telah mengubah ruang lingkup hak gugat negara (Pemerintah dan Pemda). Apabila dalam pasal 37 ayat 2 UUPLH dinyatakan bahwa gugatan negara dilakukan ketika terdapat kerugian masyarakat yang mempengaruhi kehidupan mereka, maka pasal 90 ayat 1 UUPPLH menyatakan bahwa gugatan pemerintah (dapat berupa gugatan ganti rugi atau permintahaan untuk melakukan atau tidak melakukan tindakan tertentu) hanya dapat diajukan jika terjadi "kerugian lingkungan hidup". Penjelasan ayat ini menyatakan bahwa "kerugian lingkungan hidup" adalah kerugian yang timbul akibat pencemaran dan/atau kerusakan lingkungan yang bukan merupakan hak milik privat"-(kursif dari penulis). Dengan kata lain gugatan negara muncul ketika tidak ada individu yang mengalami kerugian akibat dari pencemaran yang terjadi.

Sepintas dapat dikatakan bahwa sistem kompensasi yang hendak dikembangkan oleh UUPPLH sudah sangat baik dan mendekati sempurna. Namun demikian, ketentuan tersebut masih bersifat umum dan karenanya masih membutuhkan peraturan pelaksanaannya. Di sinilah letak persoalannya. Di Indonesia, sebuah pasal UU yang sudah sangat baik seringkali tidak berarti apa-apa karena tidak adanya peraturan pelaksanaan terhadap pasal tersebut. Misalnya saja asuransi lingkungan wajib yang telah disinggung oleh penjelasan pasal 35 ayat 1 UUPLH dalam prakteknya tidak pernah menjadi kenyataan karena peraturan pelaksanaan tentang asuransi tersebut tidak pernah ada. Tentu saja kita berharap bahwa kekeliruan ini tidak terulang kembali, karena memang UUPPLH telah mewajibkan Pemerintah dan Pemda untuk mengembangkan instrumen ekonomi, termasuk di dalamnya instrumen bagi alternatif mekanisme kompensasi.

Karenanya, meskipun di atas kertas UUPPLH telah cukup baik membuka berbagai alternatif mekanisme kompensasi, dalam prakteknya hal tersebut belum tentu menjadi kenyataan. Hal ini tentu saja merupakan sebuah persoalan, apalagi jika kita melihat bahwa ruang lingkup hak gugat negara menurut UUPPLH telah sangat berkurang dibandingkan dengan hak gugat UUPLH. Apabila pasal 90 UUPPLH tentang hak gugat negara ditafsirkan secara legalistik, maka kompensasi langsung oleh negara menjadi tidak mungkin. Hal ini terjadi karena kompensasi sudah barang tentu akan terkait dengan kerugian atas hak milik privat. Apabila pemerintah melakukan pembayaran kompensasi atas kerugian tersebut, maka pembayaran ini hanya akan menjadi beban negara karena Pemerintah telah kehilangan haknya untuk menggugat kerugian yang terkait dengan hak milik privat.

Apabila pasal 90 UUPPLH ditafsirkan seperti ini, maka hak gugat negara dalam UUPPLH jelas merupakan sebuah kemunduran, karena kompensasi langsung oleh negara sering kali merupakan satu-satunya cara yang tersedia bagi para korban pencemaran untuk memperoleh kompensasi. 
Lebih jauh lagi, terkait dengan kasus lumpur Sidoarjo, penafsiran sempit terhadap pasal 90 UUPPLH akan menghilangkan peluang kemungkinan diajukannya gugatan Pemerintah terhadap Lapindo atas penggunaan APBN untuk penanganan kasus ini.

Lampiran 1: Batas-batas Aplikasi dari Pertanggungjawaban Perdata untuk Pencemaran Lingkungan menurut EC Green Paper

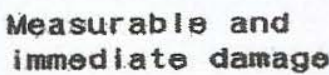

Finite act or incl dent

Ident if lable I iable partios
Unbounded or latent damage

Cumulative acts or incidents

Liability (faultbased or strict)

Un ldent if iable I Iable parties

No basis for liablitity

Causa I I ink

established

Party with legal

interest who can

bring action

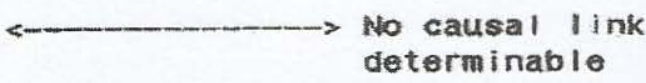

civi! lability action possible
Civil Iiability not useful : Jo int compensat ion mechan ism nooded

Sumber: 1993 EC Green Paper on Remedying

Environmental Damage, hal 24. 


\section{Lampiran 2: Risk Aversion, Asuransi, dan Premi}

Asumsikan ada seseorang, yang memiliki kekayaan awal sebesar $\mathrm{W}_{0}$, sedang mempertimbangkan untuk melakukan investasi pada sebuah usaha. Dari informasi yang dimilikinya, orang tersebut mengetahui bahwa terdapat kemungkinan besar usaha tersebut akan berhasil, sehingga kekayaannya naik menjadi $W_{1}$. Namun demikian, orang tersebut juga mengetahui bahwa terdapat sebuah kemungkinan kecil bahwa usaha tersebut akan gagal, sehingga kekayaannya turun menjadi $\mathrm{W}_{2}$.

Dari kedua kemungkinan di atas, dapat diketahui bahwa nilai ekspektasi dari usaha tersebut adalah:

$\mathrm{E}[\mathrm{W}]=\mathrm{E}\left[\mathrm{W}_{1}\right]+\mathrm{E}\left[\mathrm{W}_{2}\right]=\mathrm{p}\left(\mathrm{W}_{1}\right)+(1-\mathrm{p}) \mathrm{W}_{2}$, di mana:

- $\mathrm{E}[\mathrm{W}]$ adalah total ekspektasi nilai dari usaha;

- $\quad E\left[W_{1}\right]$ dan $E\left[W_{2}\right]$ masing-masing adalah ekspektasi nilai dari situasi yang menguntungkan $\left(W_{1}\right)$ dan ekspektasi nilai dari situasi yang merugikan $\left(\mathrm{W}_{2}\right)$;

- $\quad \mathrm{p}$ adalah probabilitas terjadinya situasi yang menguntungkan $\left(\mathrm{W}_{1}\right)$.

Pada sebuah situasi yang disebut dengan fair bet, total ekspektasi dari semua kemungkinan nilai yang ada adalah 0 . Dalam kasus kita, total ekspektasi nilai tidak mengubah kekayaan, sehingga $E[\hat{W}]=\mathrm{W}_{0}$.

Apabila orang tersebut tidak suka resiko (risk averse), dengan kurva utilitas cembung (concave) seperti pada gambar 2, maka dapat diketahui bahwa setiap nilai menghasilkan tingkat utilitasnya sendiri-sendiri, yaitu $\mathrm{W}_{1}$ menghasilkan utilitas $\mathrm{U}\left(\mathrm{W}_{1}\right), \mathrm{W}_{2}$ menghasilkan utilitas $\mathrm{U}\left(\mathrm{W}_{2}\right)$, dan total ekspektasi nilai $E[\hat{W}]$ menghasilkan utilitas $\mathrm{U}(E[\hat{W}])$.

Adanya dua kemungkinan utilitas yang muncul dari adanya dua kemungkingan situasi menghasilkan total ekspektasi utilitas sebesar: $\mathrm{E}[\mathrm{U}(\hat{\mathrm{W}})]=p \cdot \mathrm{U}\left(\mathrm{W}_{1}\right)+(1-p) \cdot \mathrm{U}\left(\mathrm{W}_{2}\right)$, di mana:

- $\quad E[U(\hat{W})]$ adalah total ekspektasi utilitas usaha;

- $\quad U\left(W_{1}\right)$ adalah utilitas dari situasi yang menguntungkan $\left(W_{1}\right)$;

- $\quad p$ adalah probabilitas terjadinya situasi yang menguntungkan;

- $\mathrm{U}\left(\mathrm{W}_{2}\right)$ adalah utilitas dari situasi yang merugikan.

Untuk orang yang risk neutral, ekspektasi utilitas usaha akan sama dengan utilitas dari total ekspektasi nilai. Akan tetapi, seperti terlihat pada gambar, untuk orang yang tidak suka resiko, ekspektasi utilitas usaha akan lebih rendah dari pada utilitas dari total ekspektasi nilai: $E[U(\hat{W})]<U(E[\hat{W}])$. Hal ini terjadi karena keberadaan resiko akan mengurangi tingkat utilitas dari orang yang tidak suka resiko. 


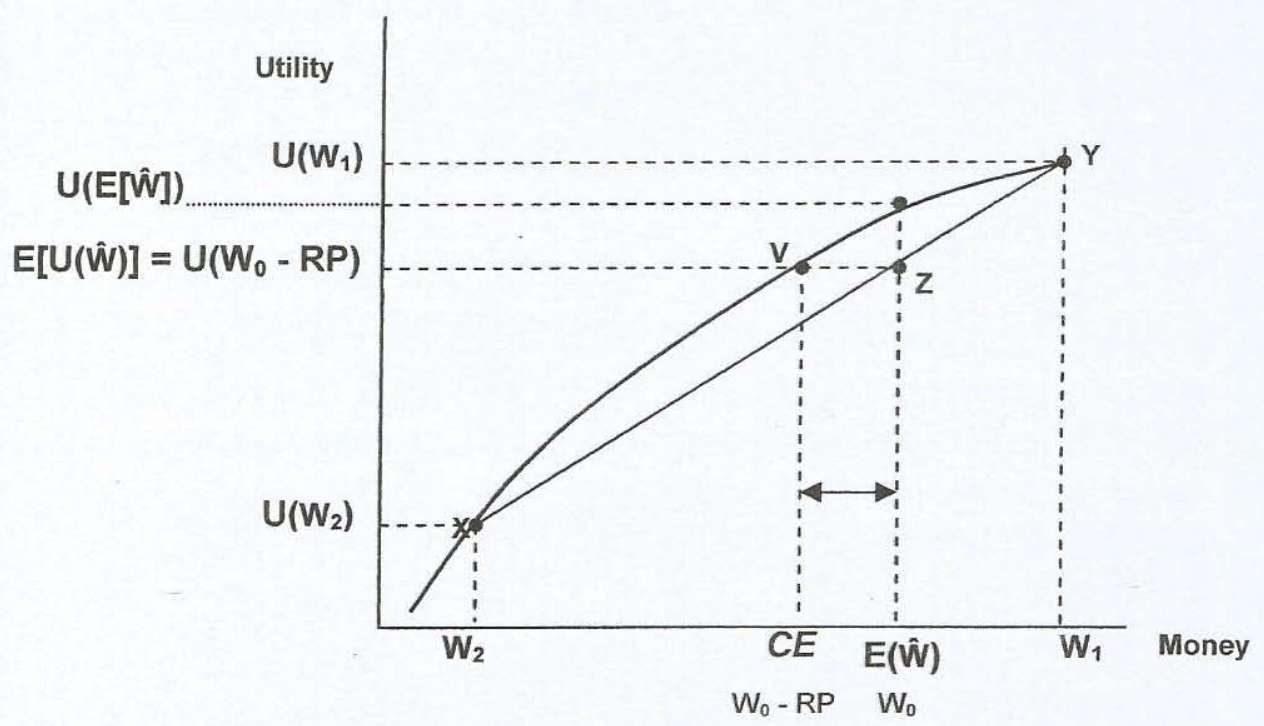

Gambar 1. Risk Averse and Risk Premium

Dari gambar terlihat bahwa garis vertikal dari ekspektasi nilai $E[\hat{W}]$ memotong garis antara X dan Y pada titik Z. Dengan demikian, kordinat vertikal dari titik $Z$ adalah ekspektasi utilitas, sedang kordinat horisontalnya adalah rata-rata dari ekspektasi nilai, $\mathrm{E}[\hat{\mathrm{W}}]$. Terlihat pula bahwa apabila kita menarik garis horizontal dari titik $\mathrm{Z}$, maka garis itu akan memutung kurva utilitas pada titik V. Titik ini mengindikasikan bahwa ada sejumlah uang yang memiliki nilai utilitas yang sama dengan utilitas dari ekspektasi nilai. Uang inilah yang disebut sebagai "certainty equivalent" (CE). Perbedaan antara certainty equivalent dan ekspektasi nilai inilah yang disebut sebagai premi, "risk premium" (RP), yaitu maksimum uang yang dapat dibayarkan oleh orang yang tidak suka resiko guna menghindari resiko. Dari pada mengalami kerugian yang besar namun tidak pasti, orang yang tidak resiko akan memilih mengalami kerugian yang kecil namun pasti dalam bentuk pembayaran premi.

Konsep penting lainnya dalam penentuan premi adalah varian dan standard deviasi, yaitu sebuah gambaran tentang dispersi yang terjadi pada variable acak. Varian adalah kuadrat dari perbedaan ekspektasi antara ekspektasi nilai dan hasil yang sebenarnya. Standar deviasi, $\sigma_{\mathrm{w}}$, adalah akar kuadrat dari varian yang menjelaskan perbedaan antara ekspektasi nilai dan hasil yang sebenarnya. Semakin besar standard deviasi, maka sebuah aktivitas menjadi semakin beresiko. 
Secara umum, varian dari hasil-hasil yang mungkin timbul adalah:

$$
\begin{aligned}
\sigma_{w}{ }^{2} & =E\left[(\hat{W}-E[\hat{W}])^{2}\right] \\
& =E\left[\hat{W}^{2}\right]-E[\hat{W}]^{2}
\end{aligned}
$$

Penting pula untuk dicatat di sini bahwa untuk situasi fair bet, $E[\hat{W}]$ adalah 0 (nol), yang berarti bahwa ekspektasi kekayaan tidak akan berubah dengan adanya resiko. Karena $E[\hat{W}]$ sama dengan 0 (nol), varian dari fair bet sama dengan $E\left[\hat{W}^{2}\right]$.

Untuk mengukur besarnya premi yang akan dibayarkan guna menghindari resiko, Arrow dan Prat mencapai kesimpulan bahwa premi tersebut adalah sebesar: ${ }^{49}$

$$
R P=1 / 2 . \sigma_{w}{ }^{2} \cdot \frac{U^{\prime \prime}\left(W_{0}\right)}{U^{\prime}\left(W_{0}\right)}
$$

Di mana:

- $\quad \sigma_{w}{ }^{2}$ adalah varian dari sebuah situasi beresiko;

- $U^{\prime \prime}\left(W_{0}\right)$ dan $U^{\prime}\left(W_{0}\right)$ masing-masing adalah turunan kedua dan turunan pertama dari fungsi utilitas terhadap penghasilan/kekayaan awal $\left(\mathrm{W}_{0}\right)$.

- $\frac{U^{\prime \prime}\left(W_{0}\right)}{U^{\prime}\left(W_{0}\right)}$ adalah koefisien Arrow-Pratt untuk ketidaksukaan akan resiko secara absolut, absolute risk aversion (A). Karena itu, persamaan di atas dapat pula ditulis sebagai:

$$
R P=1 / 2 \sigma_{w}{ }^{2} \cdot A
$$

Dari persamaan ini terlihat bahwa besaran nilai premi secara proporsional akan mengikuti tingkat varian dari sebuah resiko dan tingkat ketidaksukaan terhadap resiko (A). Sebuah aktivitas yang memiliki resiko besar menuntut premi yang lebih besar. Di samping itu, untuk tingkat resiko

${ }^{49}$ Lihat: J.W. Pratt, 1964, "Risk Aversion in the Small and in the Large", Econometrica, Vol.32, hal. 122-136; K.J. Arrow, 1971, Essays in the Theory of Risk Bearing (Amsterdam: Nord Holland). Beberapa pengarang menggunakan pendekatan yang berbeda untuk menjelaskan temuan Arrow dan Pratt tentang nilai premi di atas. Lihat misalnya: H. Gravelle dan R. Rees, 1992, Microeconomics, $2^{\text {nd }}$ ed (London: Longman), hal. 565-567; T.E. Copeland dan J.F. Weston, 1988, Financial Theory and Corporate Policy, $3^{\text {rd }}$ ed. (Amsterdam: AddisonWesley), hal. 86-90, dan S.F. Leroy dan J. Werner, 2001, Principles of Financial Economics (Cambridge: Cambridge University Press), hal. 90-92. 
yang sama, orang yang memiliki ketidaksukaan terhadap resiko yang lebih besar, akan bersedia membayar premi yang lebih besar pula. ${ }^{50}$

Persamaan di atas dapat diterangkan dengan jalan sebagai berikut.

Secara definisi, orang yang tidak suka resiko akan bersikap indifferent terhadap pilihan apakah akan mengambil resiko (dengan kemungkinan menderita kerugian besar yang belum pasti) atau membayar sejumlah uang (yang berarti mengalami kerugian yang pasti) yang dapat menghindari resiko tersebut. Ini berarti:

$$
E\left[U\left(W_{o}+\hat{W}\right)\right]=U\left(W_{o}-R P\right)
$$

Dengan menggunakan urutan kedua (second order) dari Taylor's series expansion untuk persamaan di sebelah kiri pada persamaan (1), kita akan dapatkan:

$$
\begin{gathered}
E\left[U\left(W_{o}+\hat{W}\right)\right] \approx \\
E\left[U\left(W_{o}\right)+\hat{W} \cdot U^{\prime}\left(W_{o}\right)+1 / 2 \hat{W}^{2} U^{\prime \prime}\left(W_{o}\right)\right] \ldots(2)
\end{gathered}
$$

Karena $\mathrm{W}_{0}$ tidak bersifat stokastik, $\mathrm{U}\left(\mathrm{W}_{0}\right), \mathrm{U}^{\prime}\left(\mathrm{W}_{0}\right), \mathrm{U}^{\prime \prime}\left(\mathrm{W}_{0}\right)$ menjadi konstan dan tidak tergantung pada variabel random $\hat{W}$. Karena itu, persamaan (2) dapat pula ditulis:

$$
\begin{aligned}
& E\left[U\left(W_{o}+\hat{W}\right)\right] \\
& U\left(W_{o}\right)+E[\hat{W}] \cdot U^{\prime}\left(W_{o}\right)+1 / 2 E\left[\hat{W}^{2}\right] \cdot U^{\prime \prime}\left(W_{o}\right) \ldots . \\
& \text { Untuk situasi fair bet, berlaku dua hal: } \\
& E[\hat{W}]=0 \text {, dan } \\
& \sigma_{w}{ }^{2}=E\left[(\hat{W}-E[\hat{W}])^{2}\right]=E\left[(\hat{W}-0)^{2}\right]=E[\hat{W}]^{2}
\end{aligned}
$$

Karena itu, persamaan (3) sama dengan:

$$
E\left[U\left(W_{o}+\hat{W}\right)\right] \approx U\left(W_{o}\right)+1 / 2 \cdot \sigma_{w}{ }^{2} \cdot U^{n}\left(W_{o}\right) \ldots(4)
$$

Dengan menggunakan urutan pertama (first order) dari Taylor's series expansion untuk persamaan di sebelah kanan pada persamaan (1), kita akan mendapatkan:

$$
U\left(W_{o}-R P\right) \approx U\left(W_{o}\right)-R P . U^{\prime}\left(W_{o}\right)
$$

Dengan menggabungkan persamaan (4) dan (5), akan diperoleh:

$$
U\left(W_{o}\right)+1 / 2 . \sigma_{w}{ }^{2} \cdot U^{\prime \prime}\left(W_{o}\right)=U\left(W_{o}\right)-R P \cdot U^{\prime}\left(W_{o}\right) \ldots(6)
$$

Untuk memperoleh nilai RP, persamaan(6) dapat ditulis ulang sebagai:

${ }^{50}$ H. Gravelle and R. Rees, Op. Cit., p. 566. 


$$
\begin{aligned}
R P & =1 / 2 \cdot \sigma_{w}{ }^{2} \cdot \frac{U^{\prime \prime}\left(W_{o}\right)}{U^{\prime}\left(W_{o}\right)} \ldots \\
& =1 / 2 \cdot \sigma_{\mathrm{w}}{ }^{2} \cdot A \ldots(7 \mathrm{~b})
\end{aligned}
$$

\begin{tabular}{|c|c|c|c|}
\hline $\begin{array}{c}\text { Mekanisme } \\
\text { Kompensas } \\
\mathbf{i}\end{array}$ & $\begin{array}{l}\text { Rejim UU No. 23/1997 } \\
\text { (UUPLH) }\end{array}$ & \begin{tabular}{|l} 
Rejim UU \\
No. $24 / 2007$ \\
tentang \\
Penanggul \\
angan \\
Bencana \\
\end{tabular} & $\begin{array}{l}\text { Rejim UU Perlindungan dan } \\
\text { Pengelolaan Lingkungan Hidup } \\
\text { (UUPPLH) }\end{array}$ \\
\hline & $\begin{array}{l}\text { Dasar } \\
\text { pertanggungjawaban }\end{array}$ & $\begin{array}{l}\text { - PMH } \\
\text { (pasal 34) } \\
\text { - Strict } \\
\text { liability } \\
\text { (pasal 35) }\end{array}$ & $\begin{array}{l}\text { - PMH (pasal } 87 \\
\text { ayat 1) } \\
\text { - Strict liability } \\
\text { (pasal 88) }\end{array}$ \\
\hline $\begin{array}{l}\text { Pertanggun } \\
\text { g-jawaban } \\
\text { perdata }\end{array}$ & Prosedur (hak gugat) & $\begin{array}{l}\text { - Class } \\
\text { action } \\
\text { (pasal } 37 \\
\text { ayat 1) } \\
\text { - Hak } \\
\text { gugat } \\
\text { pemerinta } \\
\text { h (pasal } \\
37 \text { ayat 2) } \\
\text { - Hak } \\
\text { gugat } \\
\text { LSM } \\
\text { (pasal 38) }\end{array}$ & $\begin{array}{l}\text { Class action } \\
\text { (pasal 91) } \\
\text { Hak gugat LSM } \\
\text { (pasal 92) } \\
\text { Hak gugat } \\
\text { pemerintah dan } \\
\text { pemerintah } \\
\text { daerah (pasal } \\
\text { 90) } \\
\text { - Hak gugat } \\
\text { warga negara } \\
\text { untuk } \\
\text { melakukan } \\
\text { gugatan } \\
\text { administratif } \\
\text { (pasal 93) }\end{array}$ \\
\hline $\begin{array}{l}\text { Asuransi } \\
\text { tanggung } \\
\text { jawab }\end{array}$ & $\begin{array}{l}\text { - Dibuka kemungkinan } \\
\text { asuransi tanggung } \\
\text { jawab wajib } \\
\text { (penjelasan pasal } 35 \\
\text { ayat 1) yang dikaitkan } \\
\text { dengan pembatasan } \\
\text { ganti kerugian pada } \\
\text { strict liability } \\
\end{array}$ & Tidak diatur & $\begin{array}{l}\text { Dibuka kemungkinan sebagai } \\
\text { asuransi lingkungan dalam konteks } \\
\text { instrumen insentif/disinsentif (pasal } \\
42 \text { ayat } 2 \text { jo. Pasal } 43 \text { ayat } 3 \text { ) }\end{array}$ \\
\hline $\begin{array}{l}\text { Jaminan } \\
\text { keuangan } \\
\text { lainnya }\end{array}$ & Tidak diatur & Tidak diatur & $\begin{array}{l}\text { - Dibuka kemungkinan dalam } \\
\text { bentuk dana jaminan pemulihan } \\
\text { (pasal } 43 \text { ayat } 2 a \text { ) } \\
\text { - Dibuka kemungkinan dalam } \\
\text { bentuk asuransi lingkungan (pasal } \\
42 \text { ayat } 2 \text { jo. Pasal } 43 \text { ayat } 3 f \text { ) } \\
\end{array}$ \\
\hline $\begin{array}{l}\text { Asuransi } \\
\text { kerugian } \\
\text { lingkungan }\end{array}$ & Tidak diatur & Tidak diatur & $\begin{array}{l}\text { Dibuka kemungkinan sebagai } \\
\text { asuransi lingkungan dalam konteks } \\
\text { instrumen insentif/disinsentif (pasal } \\
42 \text { ayat } 2 \text { jo. Pasal } 43 \text { ayat } 3 f \text { ) } \\
\end{array}$ \\
\hline Asuransi & Tidak diatur & Tidak diatur & Dibuka kemungkinan sebagai \\
\hline
\end{tabular}

\section{Lampiran 3. Mekanisme Kompensasi di Indonesia}




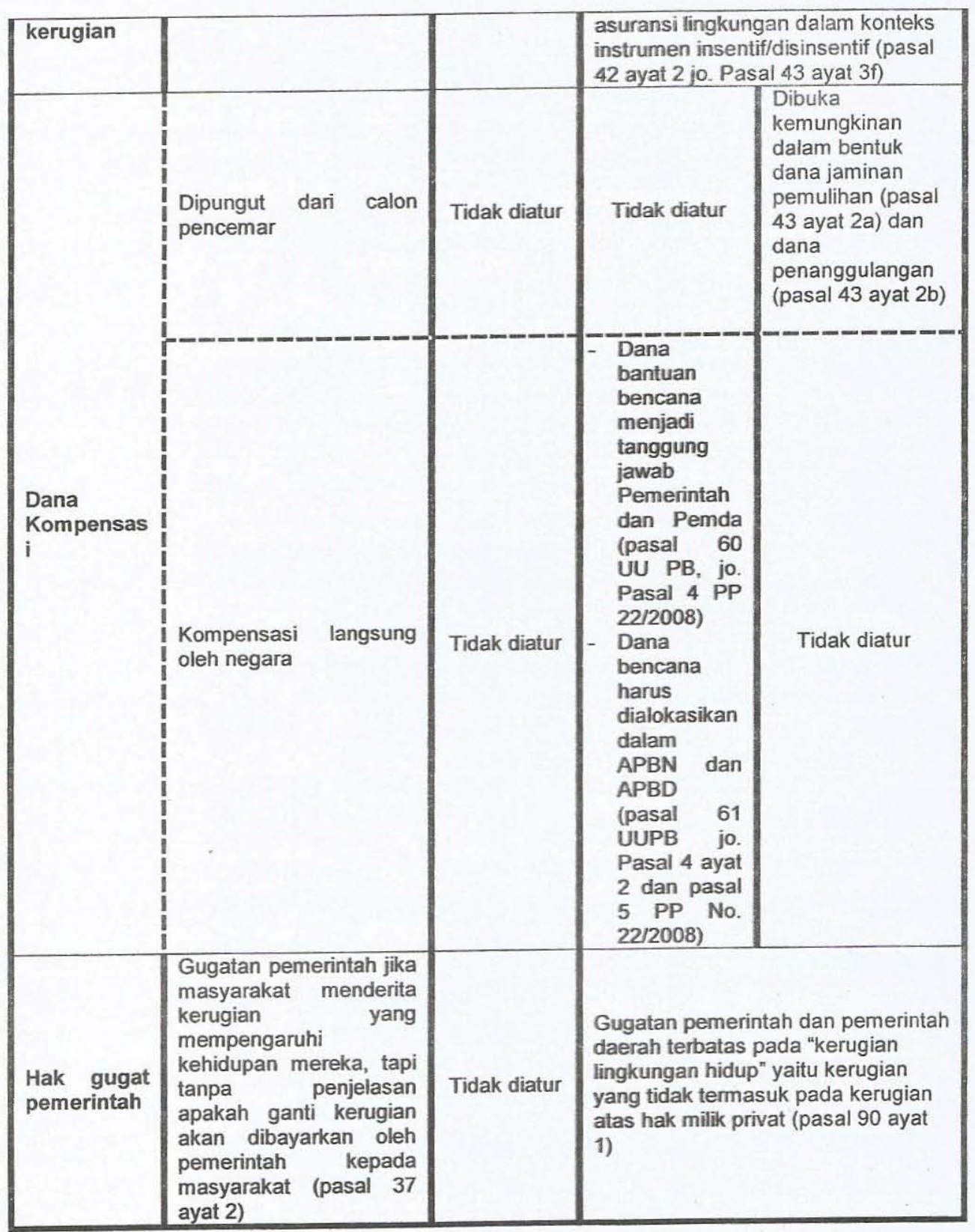




\section{Daftar Pustaka}

Arrow, K.J. Essays in the Theory of Risk Bearing. Amsterdam: Nord Holland, 1971.

Bocken, H. "Alternatives to Liability and Liability Insurance for the Compensation of Pollution Damages 1", Tijdscrift voor Milieu Aansprakelijkheid, Vol. 4, 1987: 83-87.

Bocken, H. "Alternatives to Liability and Liability Insurance for the Compensation of Pollution Damages 2", Tijdscrift voor Milieu Aansprakelijkheid, Vol. 1, 1988: 3-10.

Boyd, J. "A Market-Based Analysis of Financial Insurance Issues Associated with US Natural Resource Damage Liability", Dalam: Faure, M. (ed.). 2003. Deterrence, Insurability, and Compensation in Environmental Liability: Future Developments in the European Union. Vienna: Springer, 2003: 258-302.

Commission of European Communities. "Communication from the Commission to the Council and Parliament and the Economic and Social Committee: Green Paper on Remedying Environmental Damage”, COM (93) 47 Final, May 14, 1993.

Cooter, R. dan T. Ulen. Law and Economics, $3^{\text {rd }}$ ed. New York: Addison Wesley Longman, 2000

Copeland, T.E. dan J.F. Weston. Financial Theory and Corporate Policy, $3^{\text {rd }}$ ed. Amsterdam: Addison-Wesley, 1988.

Faure, M. (ed.). Deterrence, Insurability, and Compensation in Environmental Liability: Future Developments in the European Union. Vienna: Springer, 2003.

Faure, M. "Alternative Compensation Mechanisms as Remedies for Uninsurability of Liability", The Geneva Papers on Risk and Insurance, Vol. 29, No. 3, 2004: 455-489.

Faure, M. "Economic Criteria for Compulsory Insurance", The Geneva Papers on Risk and Insurance: Issues and Practice, Vol. 31, 2006: 149-168.

Faure, M. "A Shift toward Alternative Compensation Mechanisms for Environmental Damage?", Dalam: Faure, M. dan A. Verheij (eds.). 2007. Shifts in Compensation for Environmental Damage. Vienna: Springer, 2007: 73-102. 
Faure, M. "Financial Compensation for Victims of Catastrophes: A Law and Economics Perspective”, Law and Policy, Vol. 29, No. 3, 2007: 339367.

Faure, M. dan A. Verheij (eds.). Shifts in Compensation for Environmental Damage. Vienna: Springer, 2007.

Faure, M. dan A.G. Wibisana. "Behavioral Law and Economics: The Consequences for economic Models of Liability and Insurance", Makalah disampaikan pada lokakarya Searcing for New Models in The Economic Analysis of Law, University of Messina, Italy 25-27 Maret 2007.

Faure, M. dan D. Grimeaud. "Part I: Financial Assurance Issues of Environmental Liability”, Dalam: Faure, M. (ed.).2003. Deterrence, Insurability, and Compensation in Environmental Liability: Future Developments in the European Union. Vienna: Springer, 2003: 7-255.

Faure, M. dan T. Hartlief. "Compensation Funds versus Liability and Insurance for Remedying Environmental Damage", Review of European Community and International Environmental Law, Vol. 5, Issue 4, 1996: 321-327.

Faure, M. dan T. Hartlief, Policy Issues in Insurance: Insurance and Expanding Systemic Risks. Paris: OECD, 2003.

Gravelle, H. dan R. Rees. Microeconomics, $2^{\text {nd }}$ ed. London: Longman, 1992

Harrington, S.E. "Rethinking Disaster Policy”, Regulation, Vol. 23, No. 1, 2000: 40-46.

Leroy, S.F. dan J. Werner. 2001. Principles of Financial Economics, Cambridge: Cambridge University Press.

Pindyck, R.S. dan D.L. Rubenfield, Microeconomics, New Jersey: Prentice Hall, 2001.

Polinsky, A.M. dan S. Shavell. "Optimal Cleanup and Liability after Environmentally Harmful Discharges", NBER Working Paper, No. 4176, 1992

Pratt, J.W. "Risk Aversion in the Small and in the Large", Econometrica, Vol.32, 1964: 122-136;

Reasuransi Nasional Indonesia. "Technical Liability Insurance Workshop: Focusing on Professional Indemnity, Product Liability and CGL",. Makalah disampaikan pada lokakarya Technical Liability Insurance Workshop, Jakarta 27 \& 28 April 2009. Shavell, S. "Liability for 
571 Jurnal Hukum dan Pembangunan Tahun ke-39 No.4 Oktober-Desember 2009

Harm versus Regulation of Safety", Journal of Legal Studies, Vol. 13, 1984: 357-374.

Shavell, S. "The Judgment Proof Problem", International Review of Law and Economic, Vol. 6, 1986: 45-58.

Shavell, S. "Economic Analysis of Accident Law", NBER Working Paper No. 9694, 2003.

Solberg, E.J. Intermediate Microeconomics, Texas: Business Publication, 1982. 